\title{
The Imbert Formation of northern Hispaniola: a tectono-sedimentary record of arc-continent collision and ophiolite emplacement in the northern Caribbean subduction-accretionary prism
}

\author{
J. Escuder-Viruete ${ }^{1}$, Á. Suárez-Rodríguez ${ }^{2}$, J. Gabites ${ }^{3}$, and A. Pérez-Estaún ${ }^{4, \dagger}$ \\ ${ }^{1}$ Instituto Geológico y Minero de España, La Calera 1, 28760 Tres Cantos, Madrid, Spain \\ ${ }^{2}$ Instituto Geológico y Minero de España, Av. Real 1, 24006 León, Spain \\ ${ }^{3}$ Pacific Centre for Isotopic and Geochemical Research, University of British Columbia, 6339 Stores Road Vancouver, \\ BC V6T-1Z4, Canada \\ ${ }^{4}$ Instituto Ciencias Tierra Jaume Almera-CSIC, Lluís Solé Sabarís s/n, 08028 Barcelona, Spain \\ $\dagger$ deceased
}

Correspondence to: J. Escuder-Viruete (j.escuder@igme.es)

Received: 11 May 2015 - Published in Solid Earth Discuss.: 26 June 2015

Revised: 22 September 2015 - Accepted: 8 December 2015 - Published: 15 January 2016

\begin{abstract}
In northern Hispaniola, the Imbert Formation (Fm) has been interpreted as an orogenic "mélange" originally deposited as trench-fill sediments, an accretionary (subduction) complex formed above a SW-dipping subduction zone, or the sedimentary result of the early oblique collision of the Caribbean plate with the Bahama Platform in the middle Eocene. However, new stratigraphical, structural, geochemical and geochronological data from northern Hispaniola indicate that the Imbert Fm constitutes a coarsening-upward stratigraphic sequence that records the transition of the sedimentation from a pre-collisional forearc to a syn-collisional basin. This basin was transported on top of the Puerto Plata ophiolitic complex slab and structurally underlying accreted units of the Rio San Juan complex, as it was emplaced onto the North America continental margin units.

The Imbert Fm unconformably overlies different structural levels of the Caribbean subduction-accretionary prism, including a supra-subduction zone ophiolite, and consists of three laterally discontinuous units that record the exhumation of the underlying basement. The distal turbiditic lower unit includes the latest volcanic activity of the Caribbean island arc; the more proximal turbiditic intermediate unit is moderately affected by syn-sedimentary faulting; and the upper unit is a (chaotic) olistostromic unit, composed of serpentinite-rich polymictic breccias, conglomerates and
\end{abstract}

sandstones, strongly deformed by syn-sedimentary faulting, slumping and sliding processes. The Imbert Fm is followed by subsidence and turbiditic deposition of the overlying El Mamey Group.

The ${ }^{40} \mathrm{Ar} /{ }^{39} \mathrm{Ar}$ plagioclase plateau ages obtained in gabbroic rocks from the Puerto Plata ophiolitic complex indicate its exhumation at $\sim 45-40 \mathrm{Ma}$ (lower-to-middle Eocene), contemporaneously to the sedimentation of the overlying Imbert Fm. These cooling ages imply the uplift to the surface and submarine erosion of the complex to be the source of the ophiolitic fragments in the Imbert Fm, during or shortly after the emplacement of the intra-oceanic Caribbean island arc onto the continental margin.

\section{Introduction}

Intra-oceanic arc systems develop as a result of subduction initiation within oceanic lithosphere and subsequent plate convergence. In this tectonic context, forearc basins form on the upper plate between the arc volcanic front and the outer-forearc high (Dickinson, 1995). They differ from the outboard trench and trench-slope basins, which form along the boundary between the two convergent plates in response 
to flexure of the subducting slab and extension of the upper plate (Draut and Clift, 2012). The distribution and nature of sedimentary sequences in a forearc basin is controlled by uplift or subsidence and by the composition of the rocks eroded from the neighbouring volcanic arc, subduction complex and continental margin (von Huene and Scholl, 1991; Dickinson, 1995; Yen and Lundberg, 2006).

Chaotic rock assemblages, often referred in a descriptive non-genetic sense as a mélange (Cowan, 1985), are commonly found in forearc and trench environments and are attributed either to tectonic, sedimentary or diapiric processes, as well as their mutual interplay and superposition (Harris et al., 2009; Festa et al., 2010; Pini et al., 2012). They are often directly linked to the subduction zone processes. However, the genesis of any chaotic rock assemblage must be deduced from both detailed analyses of its lithological content, the source of its components, and the kinematic interpretation of its fabrics, as well as independent evidence concerning its palaeotectonic setting. A particular chaotic rock assemblage is the olistostrome, which is a sedimentary body derived from diverse types of gravity mass movements, such as block slides, debris avalanches, debris flows, and hyper-concentrated turbiditic currents (Lucente and Pini, 2003). These "sedimentary mélanges" are compatible with the classic principles of stratigraphic superposition, whereas other mélange occurrences in nature do not follow these principles because they are bounded by tectonic contacts. The serpentinite-matrix mélanges typical of subduction channel complexes are examples of this last type (Krebs et al., 2008, 2011). Useful criteria to discriminate between chaotic units of sedimentary and tectonic origin are the presence or absence of soft sediment deformation, the source of the rock fragments, the nature of the fine-grained matrix, and the tectono-stratigraphic position within the accretionary prism (e.g. Festa et al., 2010). The internal structure and the sedimentary record preserved in mélanges can provide a better understanding of the tectono-stratigraphic evolution of the orogen in which they occur (e.g. Alonso et al., 2006, 2015).

The Greater Antilles orogenic belt (Fig. 1) results from the Late Cretaceous-Paleogene convergence and collision between the Caribbean island arc and the North America continental margin, which led to the closure of the intermediate proto-Caribbean oceanic domain (Escuder-Viruete et al., 2011c, 2013b; García-Casco et al., 2008; Laó Dávila et al., 2012; Mann et al., 1991; Pindell and Kennan, 2009; Stanek et al., 2009). As a result, several ophiolitic massifs were emplaced in the collisional zone, which are particularly well exposed in Cuba (Lewis et al., 2006; Marchesi et al., 2006). In northern Hispaniola, the Puerto Plata complex forms part of the subduction-accretionary prism of the Greater Antilles orogenic belt, which is constituted here by a series of accreted ophiolites, ophiolitic mélanges, intra-oceanic volcanic arcs and fragments of the southern margin of the North America continent (Escuder-Viruete et al., 2011a, b, 2013a, 2014).
In the Cordillera Septentrional (Fig. 1), remnants of a Cenozoic pre- to syn-collision forearc sedimentary basin developed over the orogenic prism are constituted by the Imbert Formation $(\mathrm{Fm})$ and the $>5 \mathrm{~km}$ thick overlying turbiditic sequence of the El Mamey Group (de Zoeten and Mann, 1991). Unlike the well-studied El Mamey Group (de Zoeten and Mann, 1991, 1999), there are various interpretations of the origin and meaning of the Imbert Fm, as well as of its spatial and temporal relationships with other sedimentary units. The Imbert Fm has been interpreted as a Paleocene-lower Eocene, deep-marine sedimentary unit deposited in the outer forearc-trench setting, presumably over the underlying Puerto Plata complex (Nagle, 1979; Pindell and Draper, 1991), an orogenic mélange originally deposited as trench-fill sediments (Pindell, 1985), an accretionary (subduction) complex formed above a SW-dipping subduction zone (Bowin and Nagle, 1982; Bourgois et al., 1982), and a sedimentary record of the cessation of subduction-related magmatism as result of the early oblique collision of the Caribbean plate with the Bahama Platform in the middle Eocene (Draper et al., 1994; de Zoeten and Mann, 1999; Hernáiz-Huerta et al., 2012).

In this contribution, we present detailed maps, stratigraphic columns, whole-rock geochemical data of volcanic rocks, and data of syn-sedimentary deformation structures of the Imbert Fm, as well as Ar-Ar cooling ages of its basement. Our main objective is to document the stratigraphy and structure of the Imbert Fm, as well as its relationships with igneous and metamorphic basement units belonging to the northern Caribbean subduction-accretionary prism. We show that the Imbert Fm is not a subduction mélange but represents a coarsening-upward sedimentary sequence with an olistostromal upper part, which unconformably overlies the supra-subduction zone (SSZ) ophiolite of the Puerto Plata complex and the suture zone of the Río San Juan complex. Our observations and data suggest that the rocks of the Imbert Fm (1) contain the latest volcanic activity of the Caribbean island arc; (2) record a change in the morphology of the forearc that was induced by uplift during the arccontinent collision and ophiolite emplacement; (3) include serpentinite-rich, chaotic rock assemblages deposited in a basin transported on top of the ophiolite; and (4) were followed by a syn-orogenic turbiditic sedimentation in a subsequent phase of regional subsidence (i.e. the El Mamey Group).

\section{Geological framework}

Located on the northern margin of the Caribbean plate, the island of Hispaniola (Fig. 1) is a tectonic collage produced by the oblique convergence to final collision of the Caribbean island-arc/back-arc system with the North American plate, which began in the Lower Cretaceous (Mann et al., 1991; Draper et al., 1994). The presence of high-P ophiolitic 


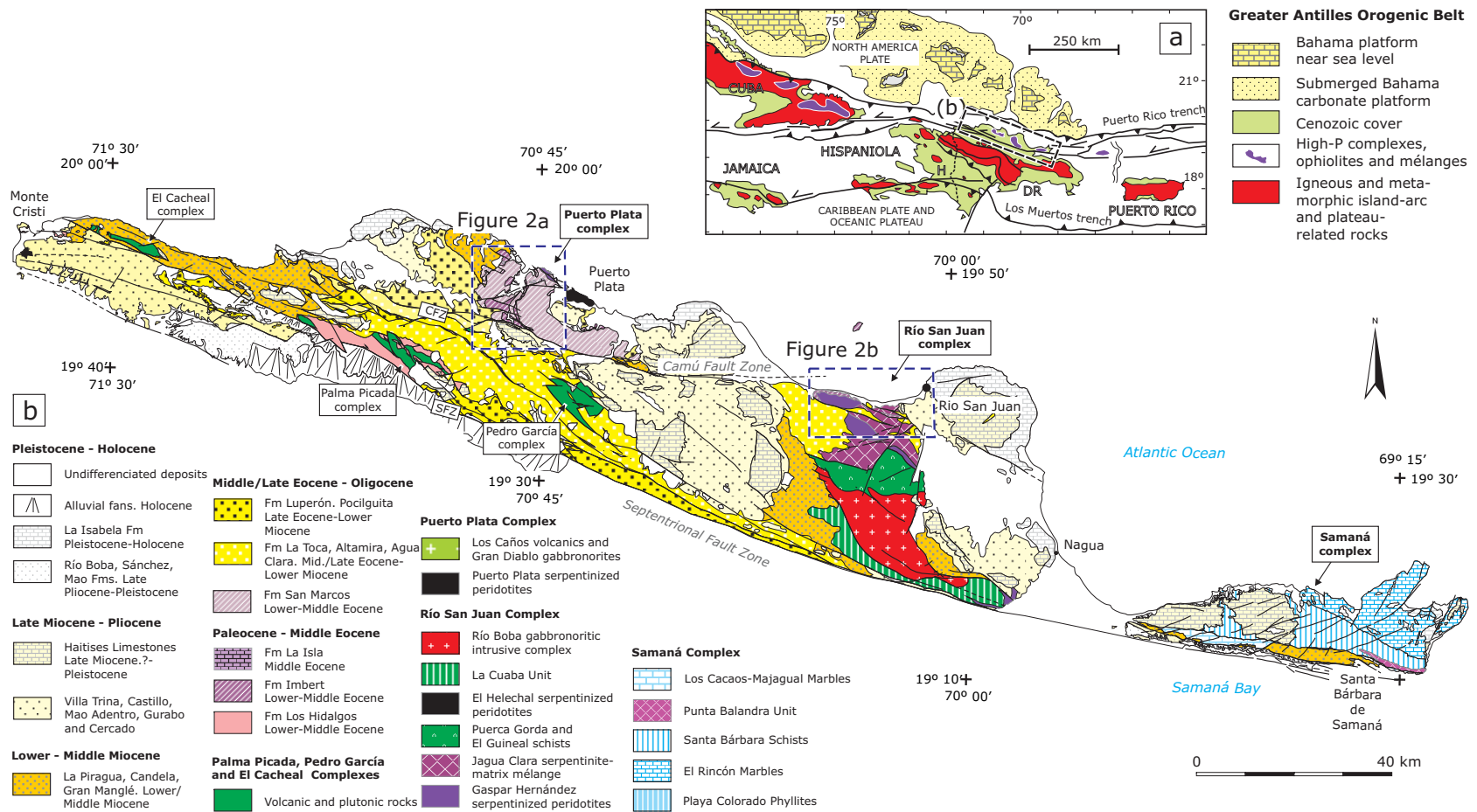

Figure 1. (a) Map of the northeastern Caribbean plate margin. Box shows location of the northern Hispaniola area. DR; Dominican Republic, H; Haiti. (b) Geological map of Septentrional Cordillera and Samaná Peninsula modified from Draper and Lewis (1991), Draper and Nagle (1991) and Escuder-Viruete (2009).

mélanges in northern Hispaniola indicates that an intermediate proto-Caribbean oceanic basin was consumed by SWdirected subduction (Draper and Nagle, 1991; Saumur et al., 2010; Escuder-Viruete et al., 2011a, c). The magmatic arcrelated rocks of the Caribbean upper plate have ages that span the Aptian-lower Eocene interval and are regionally overlain by Eocene to Holocene sedimentary rocks (Draper et al., 1994; Escuder-Viruete et al., 2006, 2008). This sedimentary cover post-dates the volcanic activity in the arc and records the oblique arc-continent collision in the northern area of the island, as well as the intra-arc and retroarc deformation in the central and southern areas.

In northern Hispaniola (Fig. 1), the pre-Eocene igneous and metamorphic substratum outcrops in several inliers, termed El Cacheal, Palma Picada, Pedro García, Puerto Plata, Río San Juan y Samaná complexes (Draper and Nagle, 1991). These six complexes form the Caribbean subductionaccretionary prism in Hispaniola (Escuder-Viruete et al., 2013a, b), and include, from $\mathrm{E}$ to $\mathrm{W}$ : metasediments of the subducted continental margin of North America; ophiolitic fragments of the proto-Caribbean lithosphere; serpentiniticmatrix mélanges with high-P blocks; and igneous rocks related to the Caribbean island arc and forearc. In the prism, the constituent tectonic units were incorporated and deformed progressively younger to the $\mathrm{E} / \mathrm{NE}$, indicating a general migration of deformation in this direction from the Late Cre- taceous to the Miocene (Escuder-Viruete et al., 2011a, b, 2013a).

\subsection{The Puerto Plata complex}

The Puerto Plata complex (PPC; Fig. 2) occupies a key position in the Caribbean subduction-accretionary prism, because it is the westernmost and structurally highest unit. It is composed of a pre-Eocene basement overlain by a sedimentary cover (Nagle, 1979; de Zoeten and Mann, 1991; Pindell and Draper, 1991; Hernáiz-Huerta, 2010; Monthel, 2010; Saumur et al., 2010). The basement consists of serpentinized peridotite, layered (cumulate) ultramafic and mafic rocks, massive gabbroic rocks, and volcanics of basic to intermediate composition, locally pillowed with rare inter-pillow cherts and limestones. These lithologies occur as tens of metres to hundreds of metres spaced fault-bounded sections of rock in a structurally disrupted or dismembered manner. On the basis of new mineral chemistry and bulk-rock geochemical data, the mafic and ultramafic rocks of the PPC has been recently interpreted as tectonically disrupted crust and mantle sections of Caribbean oceanic lithosphere, which records a Cretaceous complex history of extreme crustal thinning and related SSZ magmatism (Escuder-Viruete et al., 2014).

The ophiolitic basement is overlain by the Paleocenelower Eocene $>500 \mathrm{~m}$ thick section of the Imbert Fm (Nagle, 1979), which is composed of fine-grained turbidites in- 

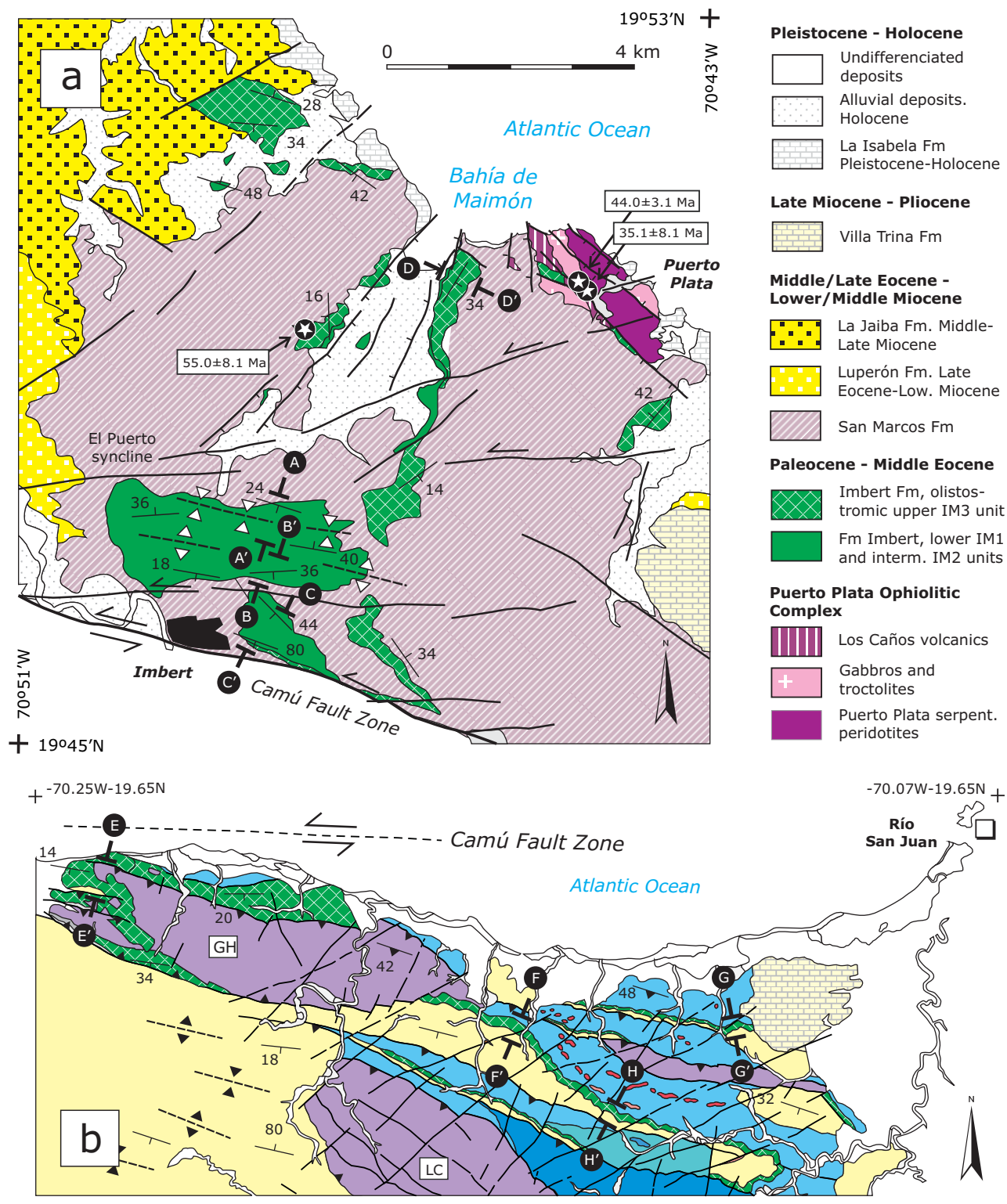

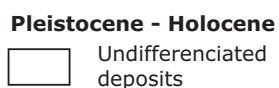

Late Miocene - Pliocene
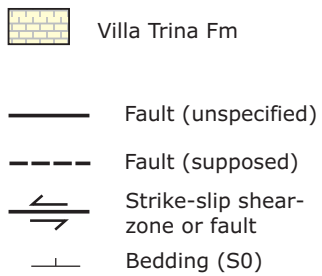

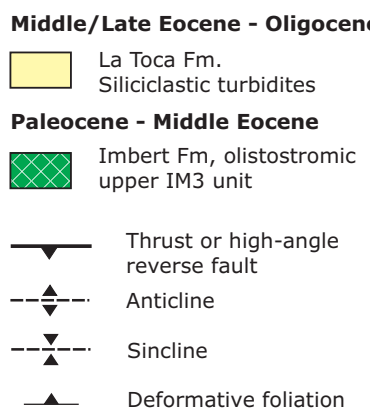

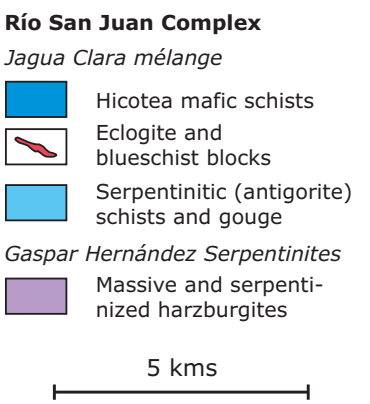

Río San Juan Complex

Jagua Clara mélange

Hicotea mafic schists

(2)

Figure 2. (a) Simplified geological map of Puerto Plata ophiolitic complex modified from Draper and Nagle (1991), Hernáiz-Huerta (2010), Escuder-Viruete et al. (2014) and Suárez-Rodríguez et al. (2015), showing locations of the El Puerto (A-A'), Rancho Brugal (B-B'), Río Obispo $\left(\mathrm{C}-\mathrm{C}^{\prime}\right)$ and Loma Seboruco $\left(\mathrm{D}-\mathrm{D}^{\prime}\right)$ sections, the location of the samples dated by ${ }^{40} \mathrm{Ar} /{ }^{39} \mathrm{Ar}$ method, and representative bedding orientations of rocks. (b) Simplified geological map of northernmost Río San Juan complex modified from Escuder-Viruete et al. (2013), showing locations of the Gaspar Hernández $\left(\mathrm{E}-\mathrm{E}^{\prime}\right)$, Magante $\left(\mathrm{F}-\mathrm{F}^{\prime}\right)$, Caño Claro $\left(\mathrm{G}-\mathrm{G}^{\prime}\right)$ and Hicotea $\left(\mathrm{H}-\mathrm{H}^{\prime}\right)$ sections, as well as representative bedding orientations of rocks. Sample location (Lat/Long): 10JE54; -70,74356/19,82547, JM9112; -70,74436/19,82614, HH9124; $-70,80958 / 19,81107$. 
terbedded with white and turquoise, very fine-grained tuffs, pelagic sediments, rare radiolarian cherts and basaltic sills. Pindell (1985) extends the unit including turbiditic beds, or debris flows, of sandstone and conglomerate that contain angular to sub-rounded lithic fragments up to $10 \mathrm{~cm}$ of serpentinites, as well as metamorphic, volcanic and green siliceous rocks. Pindell and Draper (1991) describe in detail the Imbert Fm and propose that it is coeval or slightly older than an informal unit composed of serpentinitic-rich breccias, and the lower-to-middle Eocene shallow-water limestones of the La Isla Fm, which typically contains clasts of similar serpentinites. The serpentinitic breccias are recently included at the base, and interbedded with, the lower stratigraphic section of the San Marcos Fm (Hernáiz-Huerta et al., 2012), which is a mud-matrix mélange. However, this interpretation disagrees with the presence of middle Eocene to middle Miocene faunas in sedimentary blocks included in the San Marcos Fm (Bourgeois et al., 1982; Hernáiz-Huerta, 2010; Monthel, 2010), as well as the Miocene age of the mudstone matrix (Monthel, 2010; Suárez-Rodríguez et al., 2013, 2015).

For Pindell and Draper (1991) and Hernáiz-Huerta et al. (2012), the Imbert Fm records the early collision of the Caribbean island arc with the Bahamas Platform. This is consistent with the middle to upper Eocene folding and uplift tectonic event described in the Septentrional Cordillera by Mann et al. (1991) and de Zoeten and Mann (1999), as well as in Puerto Rico (Láo Dávila et al., 2012), Haiti and southwestern Cuba (Calais et al., 1992). This tectonic event records the termination of Caribbean arc-related activity and the formed structures are older than the unconformably sedimentary base of the El Mamey Group. This group is composed by the upper Eocene to lower Miocene Altamira, La Toca and Luperón Fms, which comprise $1500 \mathrm{~m}$ of calcareous mudstones and siltstones, sandstones and conglomerates (Nagle, 1979; de Zoeten and Mann, 1999). The sequence culminates with the subhorizontal, middle Miocene to Pleistocene rocks of the Jaiba and Villa Trina Fms.

\subsection{The Río San Juan complex}

The Río San Juan complex (RSJC; Fig. 2) consists of three elements (Draper and Nagle, 1991; Krens et al., 2008, 2011; Abbott and Draper, 2013; Escuder-Viruete et al., 2013a, b): (1) a core of Mesozoic igneous and metamorphic rocks; (2) a group of Paleocene-lower Eocene to middle Miocene olistostromic, turbiditic and siliciclastic rocks (Imbert, La Toca and La Piragua Fms) that unconformably overlie the core at its periphery; and (3) a subhorizontal cover of upper Miocene to Pleistocene limestones (Villa Trina Fm). Recent work by Escuder-Viruete et al. (20113a) indicates that the large-scale internal structure of the complex consists of an imbricate stack of metamorphic rocks derived from both the Caribbean island arc and the proto-Caribbean lithosphere. In structural ascending order, the major tectonic nappes/units are the
Gaspar Hernández peridotite, the Jagua Clara serpentinitematrix mélange, and the Cuaba and Morrito units.

The Gaspar Hernández unit is composed of typical abyssal serpentinized peridotites (Saumur et al., 2010) and minor mafic sills with N-MORB geochemical signatures, suggesting that it is a fragment of the proto-Caribbean oceanic lithosphere (Escuder-Viruete et al., 2011c). The Jagua Clara mélange consists mainly of schistose and sheared, antigorite serpentinite. Blocks-in-matrix eclogites and blueschists originated from N-MORB and IAT type magmas. The retrograde exhumation of the mafic blocks and their re-equilibration to blueschist and greenschist-facies took place by Campanian-Maastrichtian time (Escuder-Viruete et al., 2013b). The Cuaba unit is mainly composed of mafic lithologies metamorphosed to amphibolite and eclogitefacies conditions. They originated from IAT and calcalkaline type protoliths (Draper and Nagle, 1991; EscuderViruete, 2010). The Morrito unit is a nappe of metavolcanic rocks (Draper and Nagle, 1991), which have boninite and IAT type compositions. These protoliths are compositionally similar to the Lower Cretaceous Caribbean islandarc rocks (Escuder-Viruete et al., 2011c). The basal thrust zone juxtaposes the Morrito unit northward onto the Jagua Clara mélange. This juxtaposition took place in the latest Maastrichtian to Paleocene, at the onset of the arc-continent collision (Escuder-Viruete et al., 2013b). The Morrito basal thrust has been interpreted as the suture zone between the upper Caribbean island-arc terranes and the lower palaeomargin of North America (Escuder-Viruete et al., 2011c).

The unconformably overlying olistostromic rocks of the Imbert Fm are mainly composed of poorly sorted angular breccias and large blocks, with subordinated sandstones, mudstones and rare white and turquoise tuffs (Draper and Nagle, 1991; Escuder-Viruete, 2009). The clasts of the breccias are mainly of serpentinite from the underlying Gaspar Hernández peridotites, but also contain clasts of Jagua Clara and Morrito metamorphic rocks. The source area for the breccias and olistostromes was probably a faultcontrolled escarpment, which indicates the exhumation of the subduction-accretionary complex to submarine exposure before the Paleocene-lower Eocene (Escuder-Viruete, 2009). The basal olistostrome is overlain by the middle Eocene to Oligocene La Toca Fm, which is $>1 \mathrm{~km}$ thick and contains mid- to thin-bedded sandstones, siltstones and marls, with rare intercalations of pebbly conglomerates and calcarenites. The sediments of the La Toca Fm are thought to have accumulated in the middle/distal area of a syn-orogenic turbiditic basin. Turbiditic sedimentation is succeeded by alluvial-fan conglomerates of the lower/middle Miocene Piragua Fm, and the upper Miocene-Pliocene marls and reefal limestones of the Villa Trina Fm. 


\subsection{Tectonic history of the Cordillera Septentrional}

De Zoeten and Mann (1999) distinguished three sedimentary intervals in the evolution of the Cordillera Septentrional, separated by distinctive regional-scale tectonic events. The first interval includes the Paleocene to lower Eocene deposition of hemipelagic, fine-grained turbidites (Los Hidalgos and Imbert Fm). Sedimentation was terminated by a folding and uplift event, which is thought to be related to early attempted subduction of the Bahama Platform beneath the Caribbean island arc. The second interval contains the upper Eocene to lower Miocene deposition of deep-marine, siliciclastic turbidites (Altamira, Las Lavas, and La Toca Fm). Siliciclastic sedimentation was terminated by a folding and uplift event, which is thought to be associated with transpressional strike-slip faulting related to North AmericaCaribbean plate motion. The third interval includes the upper Miocene to lower Pliocene deposition of shallow-marine limestones (Villa Trina Fm). Carbonate sedimentation was terminated by a folding and uplift event related to the current pattern of restraining bend tectonics (Mann et al., 2002).

\section{Stratigraphy of the Imbert Fm}

The stratigraphic relationships between the Imbert Fm and its igneous and metamorphic basement are exposed in the PPC and RSJC, which are illustrated with eight stratigraphic sections (Figs. 3 and 4). Three informal stratigraphic units characterize the Imbert Fm: a fine-grained sandstonemudstone lower IM1 unit, interbedded with fine-grained volcanic rocks (tuffs) and intruded by mafic sills; a coarsegrained sandstone-mudstone intermediate IM2 unit; and an olistostromic and heterogeneous clastic upper IM3 unit, composed of polymictic breccias, conglomerates and sandstones. In the PPC, these units are unconformable overlain by a chaotic pebbly mudstone-mudslate unit, the San Mar$\cos \mathrm{Fm}$, characterized by a block-in-matrix fabric and containing clasts of rocks similar to, and presumably derived from, all Imbert Fm units, as well as the underlying ophiolitic basement. In the RSJC, the IM1 and IM2 units are absent, and IM3 unit directly overlies the metamorphic basement. The rocks of the IM3 unit are overlain by the turbiditic sequence of the La Toca Fm, which contain in the lowermost part calcarenites with foraminifera of middle-to-upper Eocene age (Escuder-Viruete, 2009). During the fieldwork, distinctive sedimentary facies associations have been used, all of which are detailed described in the Suplement A.

\subsection{El Puerto section}

This section corresponds to the type section of the lower IM1 unit and illustrates the gradual change to the intermediate IM2 unit. The section lies along the northern flank of El Puerto syncline (A-A'; Fig. 2), where the bedding trends $\mathrm{N} 110-130^{\circ} \mathrm{E}$ and dips $14-36^{\circ}$ toward the south. The sub- stratum of the section does not outcrop. Three facies assemblages characterize the IM1 unit: thin-bedded, medium-tofine-grained sandstone $(\mathrm{Sm})$; thin-bedded alternance of finegrained sandstone, siltstone and laminated mudstone ( $\mathrm{Sf})$; and fine-grained tuff with alternating fine-grained tuffaceous sandstone and mudstone (Tv; Fig. 5h). The lower part of the section is $\sim 500 \mathrm{~m}$ thick (from 0 to $480 \mathrm{~m}$ in Fig. 3) and lacks coarse-grained rocks. It is characterized by interbedded light brown thin-bedded sandstone, dark mudstone and green parallel-laminated siltstone, in beds up to $1 \mathrm{~m}$ thick (Sf). In these hemipelagic facies Monthel (2010) found planktonic foraminifera of the lower Eocene. White, cream and turquoise coloured, fine-grained tuffs with laminated internal structure are sporadically intercalated as very thin beds $(1-3 \mathrm{~cm}$ thick) in the sequence (Tv). The upper part of the section attains $\sim 400 \mathrm{~m}$ de thickness (from 500 to $900 \mathrm{~m}$ in Fig. 3) and is also constituted by fine-grained deposits. However, this upper part is characterized by a progressive higher occurrence of interbedded $5-50 \mathrm{~cm}$ thick beds of medium-tocoarse grained sandstone $(\mathrm{Sm})$, which are characterized by size grading and planar laminations, and result a typical turbidite sequence of alternating sandstone and mudstone. The first lenticular breccias with erosive base typical of the intermediate IM2 unit occurs at $\sim 880 \mathrm{~m}$ and contains $5-20 \mathrm{~cm}-$ sized subangular serpentinite clasts in a sandy matrix composed of serpentinite, altered pyroxene, red iron oxide, chlorite and red/green mudstone. The El Puerto section is not deformed by syn-sedimentary faulting.

\subsection{Rancho Brugal section}

This section is $320 \mathrm{~m}$ thick, has a $60 \mathrm{~m}$ gap in outcrop halfway up, and corresponds to the lower IM1 unit (B-B'; Fig. 2). The lower part of the section exposes $\sim 180 \mathrm{~m}$ of alternating fine-to-medium grained sandstone ( $\mathrm{Sf}$ and $\mathrm{Sm}$ ), fine-grained tuffaceous sandstone and laminated mudstone (Tv). Bed thickness ranges from very thin-to-medium $(<30$ $\mathrm{cm}$ thick). White and cream coloured, fine-grained tuffs also occur intercalated as very thin beds. At several stratigraphic levels the section contains massive flows and sills of basalt and andesite, as well as intercalated fine-grained, mafic pyroclastic rocks. The upper part of the section is composed by a poorly exposed sequence of alternating fine-grained sandstone, siltstone and laminated mudstone $(\mathrm{Sf})$ that attain $\sim 130 \mathrm{~m}$ of thickness. Sandstone beds have a thin-to-medium thickness. This upper part of the section is in lateral continuity with the lower part of the El Puerto section.

\subsection{Río Obispo section}

This section is $580 \mathrm{~m}$ thick and corresponds to the type section of the intermediate IM2 and upper IM3 units. It is located $\sim 1 \mathrm{~km}$ east of the Imbert town and crops out over $\sim 500 \mathrm{~m}$ along the incised river valley (C-C'; Fig. 2). The bedding trends $\mathrm{N} 140-160^{\circ} \mathrm{E}$ and dips $50-85^{\circ}$ toward 


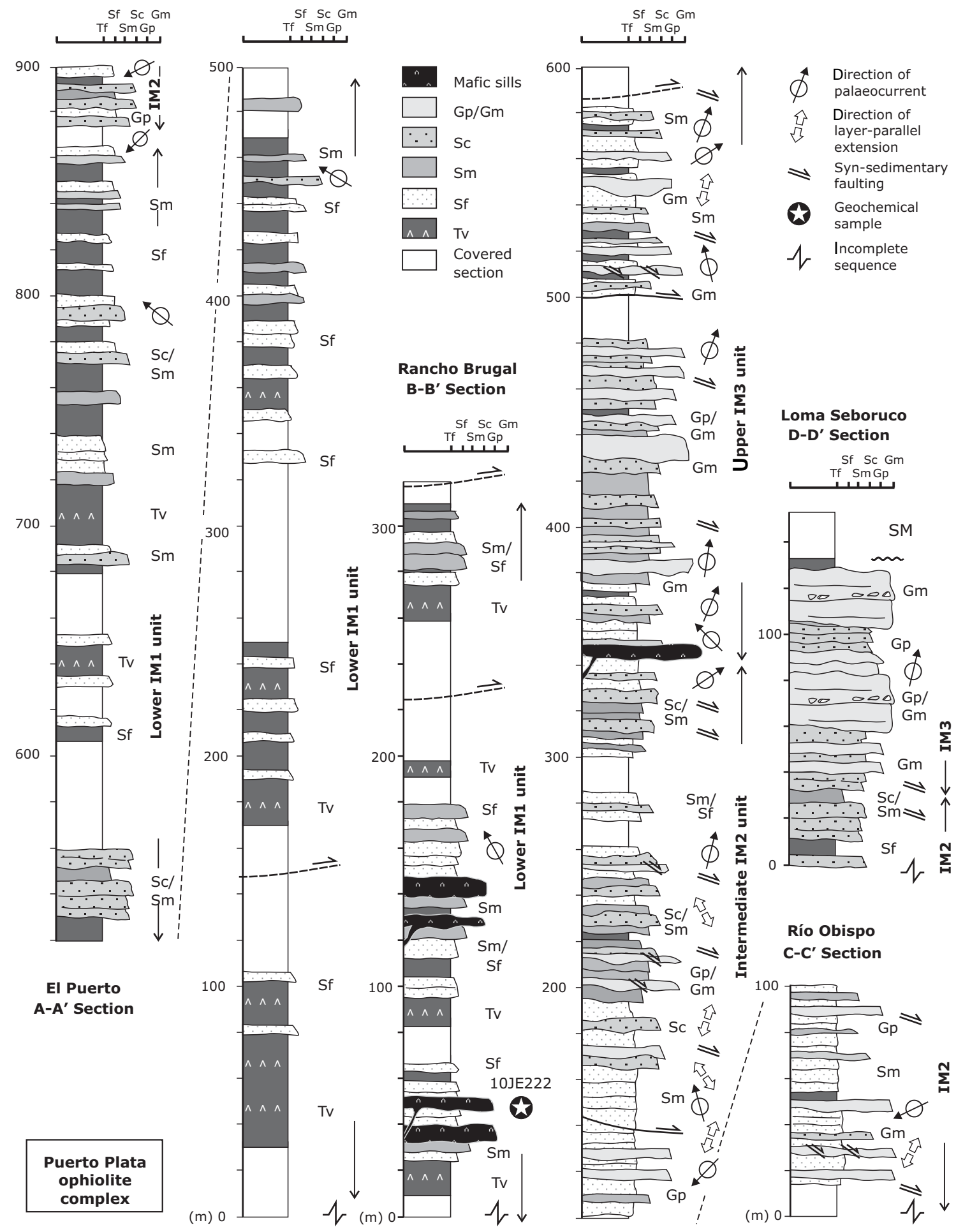

Figure 3. Stratigraphic sections of the Imbert Fm as exposed in the Puerto Plata ophiolitic complex. See text and Supplementary Material A for details and Fig. 2 for location. Sedimentary facies assemblages: Gp, clast-supported, sandy (polymictic) breccia and conglomerate; Gm, massive breccia and matrix-supported, muddy-sandy (polymictic) conglomerate; Sc, medium-to-thick bedded coarse-grained sandstone and microconglomerates; Sm, thin-bedded, medium-to-fine-grained sandstone; Sf, fine-grained sandstone, siltstone and laminated mudstone; Tv, fine-grained tuff with alternating fine-grained tuffaceous sandstone and mudstone. 

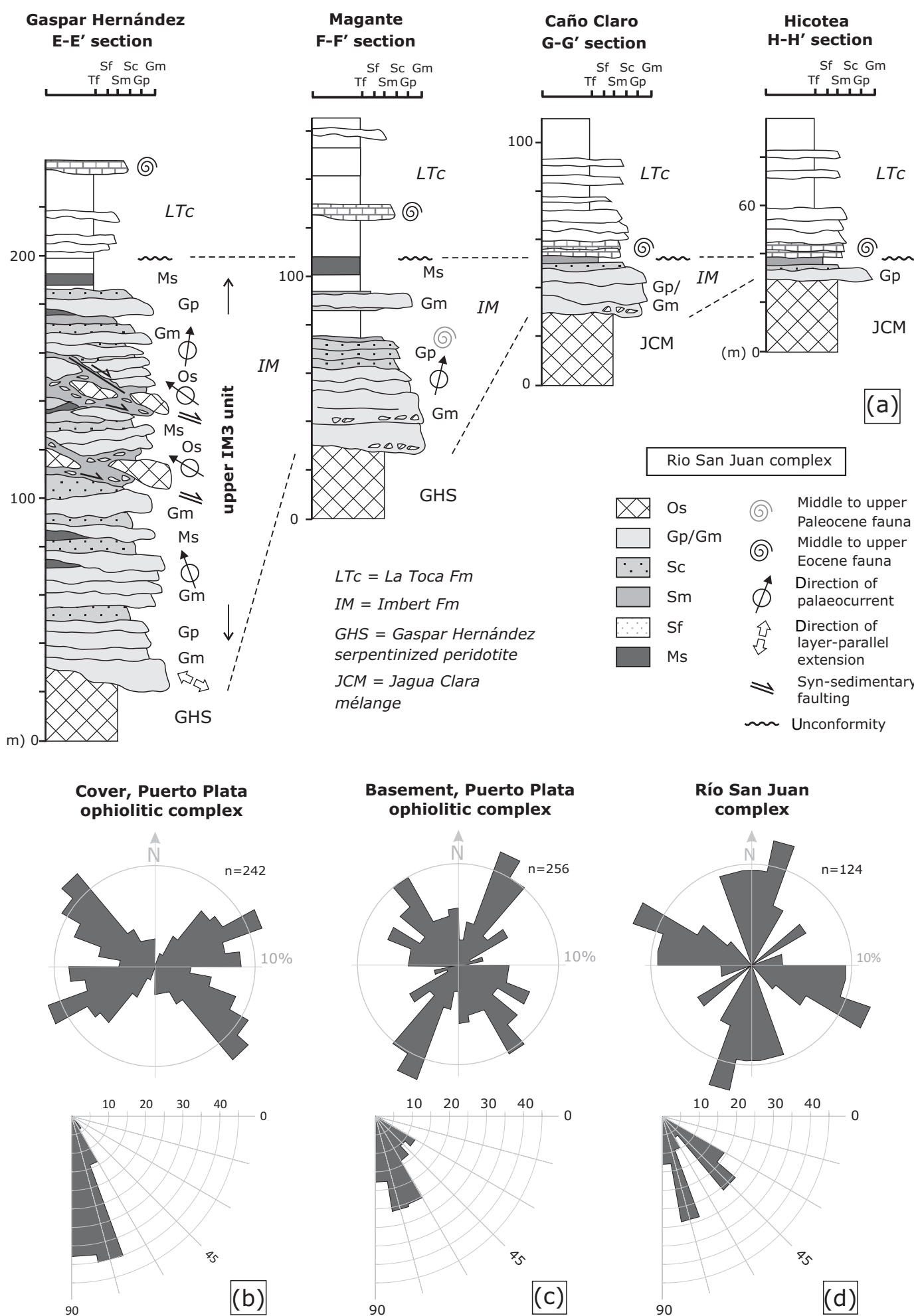
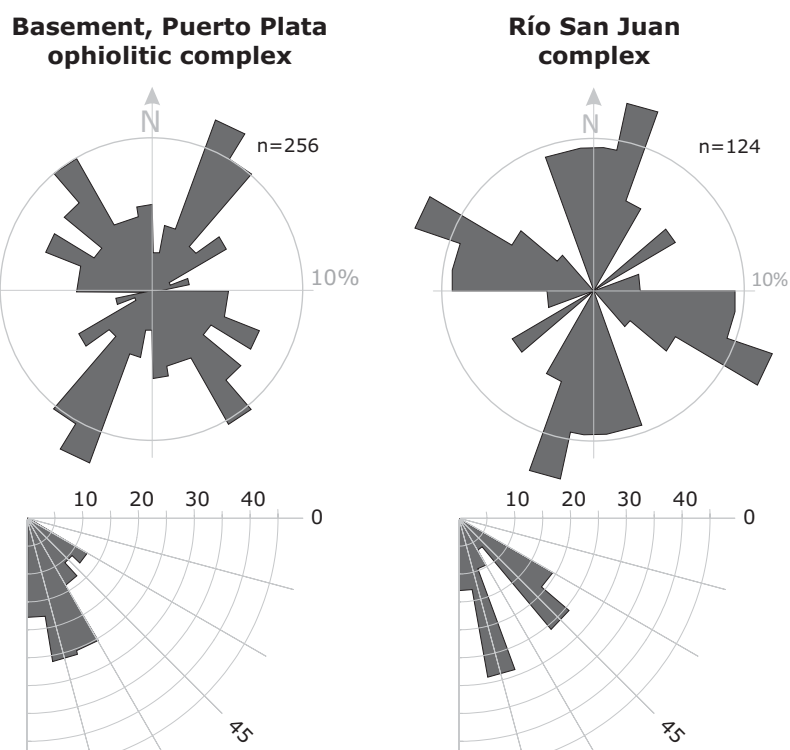

90

(c)

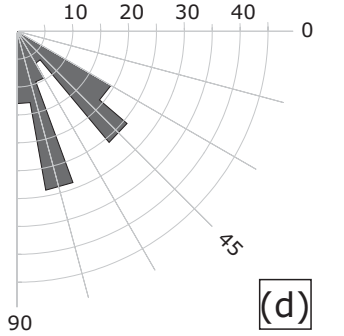

90 (d)

Figure 4. (a) Stratigraphic sections of the Imbert Fm in the Río San Juan complex. Facies assemblages as in Fig. 3, except Os which is composed by lensoidal serpentinite blocks in a heterogeneous and mostly deformed matrix composed of shale, mudstone and sandstone. See text and Supplementary Material A for details and Fig. 2 for location. Trend and dip data of syn-sedimentary joints and small faults affecting (b) the Imbert Fm in the Puerto Plata complex, (c) its ophiolitic basement, and (d) the Imbert Fm in the Río san Juan complex. 
the southwest. The sedimentary sequence is overlain by the San Marcos Fm to the east and southeast, and is truncated at a low-angle by the Camú Fault to the south. Four facies associations characterize the section: massive breccia and matrix-supported, muddy-sandy (polymictic) conglomerate $(\mathrm{Gm})$; clast-supported, sandy (polymictic) conglomerate (Gp); medium-to-thick bedded coarse-grained sandstone and micro-conglomerate (Sc); and thin-bedded, medium-tofine-grained sandstone (Sm).

The lower part of the section exposes $\sim 340 \mathrm{~m}$ of $5-70 \mathrm{~cm}$ thick beds of brown sandstone alternating with grey mudstone, with sporadic intercalations of polymictic breccias and conglomerates. Sandstone beds are commonly size-graded with channel bases and parallel-laminated tops that grade into laminated mudstone. Grain size in sandstone beds grades from fine-grained to very coarse ( $\mathrm{Sm}$ and $\mathrm{Sc}$ ), with rare argillite pebbles at the base. Sandstones are rich in volcanic lithic, volcanic plagioclase, detrital serpentinite and ferruginized grains (Fig. 6d). This assemblage of parallel-stratified sandstones and mudstones of the IM2 unit constitutes a typical turbiditic sequence, which sporadically intercalates $<1.5 \mathrm{~m}$ thick lenticular beds of clast-supported breccia and angular-to-sub-rounded conglomerates (Gp). Some parts of the section are disrupted and deformed by syn-sedimentary extensional faults (Fig. 5f, g). The upper part of the section is about $240 \mathrm{~m}$ thick (i.e. from 340 to $580 \mathrm{~m}$ in Fig. 3) and consists of thick and very thick beds of breccia and conglomerate ( $\mathrm{Gm}$ and $\mathrm{Gp}$ ), which characterize the IM3 unit (Fig. 5e). Breccias are often composed of amalgamated lenticular beds with erosive base, where individual beds are characterized by centimetre to metre sized fragments in a fine-grained matrix of sandstone and mudstone. Fragments include, in decreasing order of abundance, serpentinite, peridotite, red/green volcanic rocks, laminated sandstone, leucogabbro, (rare) white limestone, and red/green mudstone. Large fragments (up to $1 \mathrm{~m}$ ) of mudstone are found locally within the breccia and are interpreted as rip-up clasts. The breccias are overlain by, and interbedded with, sequences of $0.1-0.5 \mathrm{~m}$ thick beds of alternating coarse-grained sandstone and mudstone (Sc). This upper part is strongly deformed by syn-sedimentary extensional faults.

\subsection{Loma Seboruco section}

This section is located in the eastern Bahía de Maimón (DD'; Fig. 2) and is constituted by the upper IM3 unit. Although the lower stratigraphic contact does not outcrop, the section presumably overlies the Puerto Plata complex. The bedding trends $18-32^{\circ} \mathrm{E}$ and dips $20-36^{\circ}$ toward the east. The section can be subdivided into two parts, in which facies show a coarsening-upward evolution. The lower part exposes $\sim 30 \mathrm{~m}$ of poorly sorted, coarse-grained sandstones (Sc and $\mathrm{Sm}$ ), in beds of $0.1-0.6 \mathrm{~m}$ thick. Sandstones are rich in volcanic lithic grains and detrital serpentinite grains (Fig. 6b, c). These rocks are deformed by syn-sedimentary faulting.
The upper part attains $\sim 100 \mathrm{~m}$ (from 30 to $130 \mathrm{~m}$ in Fig. 3) and is characterized by massive, matrix- and clast-supported polymictic breccias and conglomerates ( $\mathrm{Gm}$ and $\mathrm{Gp}$ ). They are often chaotic or form a heterogeneous assemblage of clasts in a serpentinite-rich, muddy matrix. The beds have a thick to very-thick thickness and a massive internal structure. Clasts are angular to sub-rounded, of sand to coble grainsize, and are of ophiolitic and sedimentary nature (Fig. 5b, d). Ophiolitic clasts are mainly composed of variably serpentinized peridotite, with subordinate layered gabbro, leucogabbro, dolerite, basalt, and tonalite; sedimentary clasts correspond to typical lithologies of IM1 and IM2 underlying units, as graded sandstone, fine-grained tuff, tuffaceous siltstone and mudstone, as well as rare white limestone. The matrix of the breccia is a serpentinite-rich, medium-to-coarsegrained sandstone. These breccias are unconformably overlain by the sheared pebbly mudstones of the San Marcos Fm.

\subsection{Gaspar Hernández section}

This section is $\sim 240 \mathrm{~m}$ thick and lies along several quarries located in the northwestern end of the Río San Juan complex (E-E'; Fig. 2). The bedding trends N100-126 $6^{\circ} \mathrm{E}$ and dips 10 to $36^{\circ}$ toward the southwest. The sedimentary sequence corresponds to the upper IM3 unit and overlies a basement made up of the Gaspar Hernández serpentinites. Sedimentary facies show an evolution (Fig. 4, base to top) from matrix-supported polymictic breccia and conglomerate $(\mathrm{Gm})$, to lensoidal serpentinite blocks in a heterogeneous matrix (Os and Ms), and clast-supported polymictic breccia and conglomerate ( $\mathrm{Gp}$ and $\mathrm{Gm})$. In the lower part of the stratigraphic section (from 30 to $100 \mathrm{~m}$ ), the matrix-supported breccia contains $(\sim 60 \%)$ 5-20 cm-sized angular to subrounded clasts in a serpentinite-rich, muddysandy matrix (Gm; Figs. 5c, 6a). Clasts are mainly composed of serpentinite and serpentinized harzburgite, with subordinated red/green volcanic rocks, laminated sandstone, ferruginized microbreccia, porphyritic lavas, isotropic gabbro and dolerite. The breccia beds are internally massive and often have an amalgamated lenticular geometry with erosive bases. These rocks show evidence of syn-sedimentary extensional deformation. The breccias are overlain by an olistostromic intermediate subsection of lensoidal serpentinite blocks in a heterogeneous and mostly deformed matrix, composed of serpentinite-rich sandstone, pebbly mudstone and shale (Os; Fig. 5a). Block range in size from a few centimetres to several metres (up to $20 \mathrm{~m}$ ). Blocks and clasts are angular and of a similar nature than in lower breccias. Breccias are intercalated in 0.1-2 m thick beds of massive varicoloured (red, green and grey) mudstone-mudslate (Ms), which also contain serpentinitic clasts and blocks. This chaotic and strongly faulted intermediate section is at least $50 \mathrm{~m}$ thick. The upper part of the section is characterized by massive, clastsupported polymictic breccia and conglomerate (Gp, Gm). The sequence attains $\sim 30 \mathrm{~m}$ (from 160 to $190 \mathrm{~m}$ in Fig. 4). 
The beds often have a lenticular geometry, a massive or normally graded internal structure, and a clast-supported fabric. Clasts are angular and of sand to pebble grain-size. These rocks show syn-sedimentary deformation structures.

\subsection{Magante section}

This section is $\sim 10 \mathrm{~km}$ east of the Gaspar Hernández section (F-F'; Fig. 2), and also correspond to the IM3 unit, although the basement here consists of the Jagua Clara serpentinitematrix mélange. The bedding trends $\mathrm{N} 90-110^{\circ} \mathrm{E}$ and dips $60-75^{\circ}$ toward the south. The section can be subdivided into two subsections, where facies show a crudely finning-upward evolution. The lower part exposes $\sim 24 \mathrm{~m}$ (from 30 to $54 \mathrm{~m}$ in Fig. 4) of massive and matrix-supported, muddy-sandy polymictic breccia and conglomerate, with $\mathrm{cm}$-sized clasts of ophiolitic, metamorphic and sedimentary rocks $(\mathrm{Gm})$. Ophiolitic clasts are composed of serpentinite, peridotite, and various types of gabbro, dolerite and volcanic rocks. Metamorphic clasts consist of eclogite, blueschist, metagabbro and felsic orthogneiss. Sedimentary clasts are typical lithologies of IM1 unit, as brown, graded sandstone, white finegrained tuff and tuffaceous siltstone, limestone and mudstone. The matrix of the breccia is medium-to-coarse-grained sandstone, rich in serpentinite grains. In the upper part of the section, breccias have a clast-supported fabric (Gp) and are overlain by $\sim 16 \mathrm{~m}$ of well-bedded and normally graded coarse- to fine-grained sandstones. The contacts between these sandstone beds are commonly scoured. Sandstones contain reworked foraminifera of middle to upper Paleocene age (Escuder-Viruete, 2009), so they are younger in age.

\subsection{Caño Claro and Hicotea sections}

The Caño Claro and Hicotea sections are $\sim 1 \mathrm{~km}$ apart, and about and $3.5 \mathrm{~km}$ south and $9 \mathrm{~km}$ east of the Magante section $\left(\mathrm{G}-\mathrm{G}^{\prime}\right.$ and $\mathrm{H}-\mathrm{H}^{\prime}$; Fig. 2). In both sections the unconformable contact between the serpentinite-matrix mélange and the overlying IM3 unit is exposed. In the Caño Claro section, the metamorphic substrate is directly overlain by $\sim 18$ m of matrix- and clast-supported polymictic breccia and conglomerate ( $\mathrm{Gm}$ and $\mathrm{Gp}$ ), characterized by centimetre-todecimetre-sized fragments in a serpentinite-rich sandy matrix. Clasts are of similar nature that in the Magante section. Breccia and conglomerate beds (up to $2.5 \mathrm{~m}$ thick) have a crudely finning upward grading, with basal erosive surfaces and coarse-to-medium-grained sandstone tops. In the Hicotea section, the mélange is directly overlain by only 8 $10 \mathrm{~m}$ of matrix- and clast-supported, muddy-sandy polymictic breccia (Gp). The matrix contains pebble-to-coble size clasts of metamorphic rocks, such as metagabbro, eclogite and mafic blueschist. As in the Jagua Clara section, the breccias are immediately overlain by a turbiditic sequence of interbedded sandstone and mudstone of the La Toca Fm, with basal calcarenites containing middle and upper Eocene foraminifera.

\section{Volcanic rocks of the Imbert Fm and coeval units}

\subsection{Field relations and petrography}

The volcanic rocks present in the Imbert Fm form up to $10 \mathrm{~m}$ thick coherent bodies and well-stratified, fine-grained volcaniclastic rocks, which are interbedded with the fine-grained sandstones and mudstones of the IM1 lower unit (Fig. 3; Escuder-Viruete, 2010). The coherent bodies are composed of brown-to-dark green mafic rocks, forming lava flows, autoclastic breccias, and massive intrusive sills (Fig. 6e). Autoclastic breccias are generally composed of monogenetic clasts. These rocks were erupted in a submarine environment and were intruded by rare syn-volcanic, feeder dykes of microgabbro and dolerite. Fine- to very fine-grained volcaniclastic deposits are white to turquoise in colour (Fig. 5h) and are overlain, or interbedded by, ribbon cherts. Under the microscope, the coherent rocks are ortho and clinopyroxenebearing porphyritic basalts (Fig. 6f), plagioclase-phyric basalts and basaltic andesites, hornblende-phyric andesites with minor olivine, and clinopyroxene-bearing basalts. The textures are porphyritic, glomeroporphyritic, fluidal, amygdaloidal, and aphyric.

The volcanic rocks of the Palma Picada volcanic complex and the igneous rocks of the Curtiembre plutons are coeval with those of the Imbert Fm (Escuder-Viruete, 2010). Part of the Palma Picada volcanic complex crops out south of the Camú fault zone, about 1-2 km southeast of Imbert town (Fig. 1; de Zoeten and Mann, 1991, 1999). It is mainly composed of basalts, basaltic andesites and andesites, with subordinate mono and polymictic breccias and volcaniclastic rocks. The andesites have provided ${ }^{40} \mathrm{Ar} /{ }^{39} \mathrm{Ar}$ hornblende plateau ages between 51 and $46 \mathrm{Ma}$ (lower Eocene; EscuderViruete, 2010). These volcanic rocks are also in part coeval with the limestones the fine-grained volcaniclastic rocks of the Los Hidalgos Fm, which contains upper Maastrichtian to lower Eocene-age fossils. Both units are regionally unconformable overlain by the upper Eocene to Oligocene turbiditic sequence of the Altamira and La Toca Fms. Located in the Eastern Cordillera, the hornblende (Hbl)-bearing diorites of the Curtiembre plutons are geochemically similar to the volcanic rocks of the Palma Picada complex. They have yielded ${ }^{40} \mathrm{Ar} /{ }^{39} \mathrm{Ar}$ hornblende plateau ages between 68 and $63 \mathrm{Ma}$ (upper Maastrichtian to lower Paleocene; EscuderViruete, 2010). These plutons could be close to the Palma Picada complex in the Eocene and were after separated by the Septentrional fault strike-slip movement.

\subsection{Bulk-rock major and trace elements compositions}

Bulk-rock compositions of major and trace elements were obtained by inductively coupled plasma-mass spectrometry 

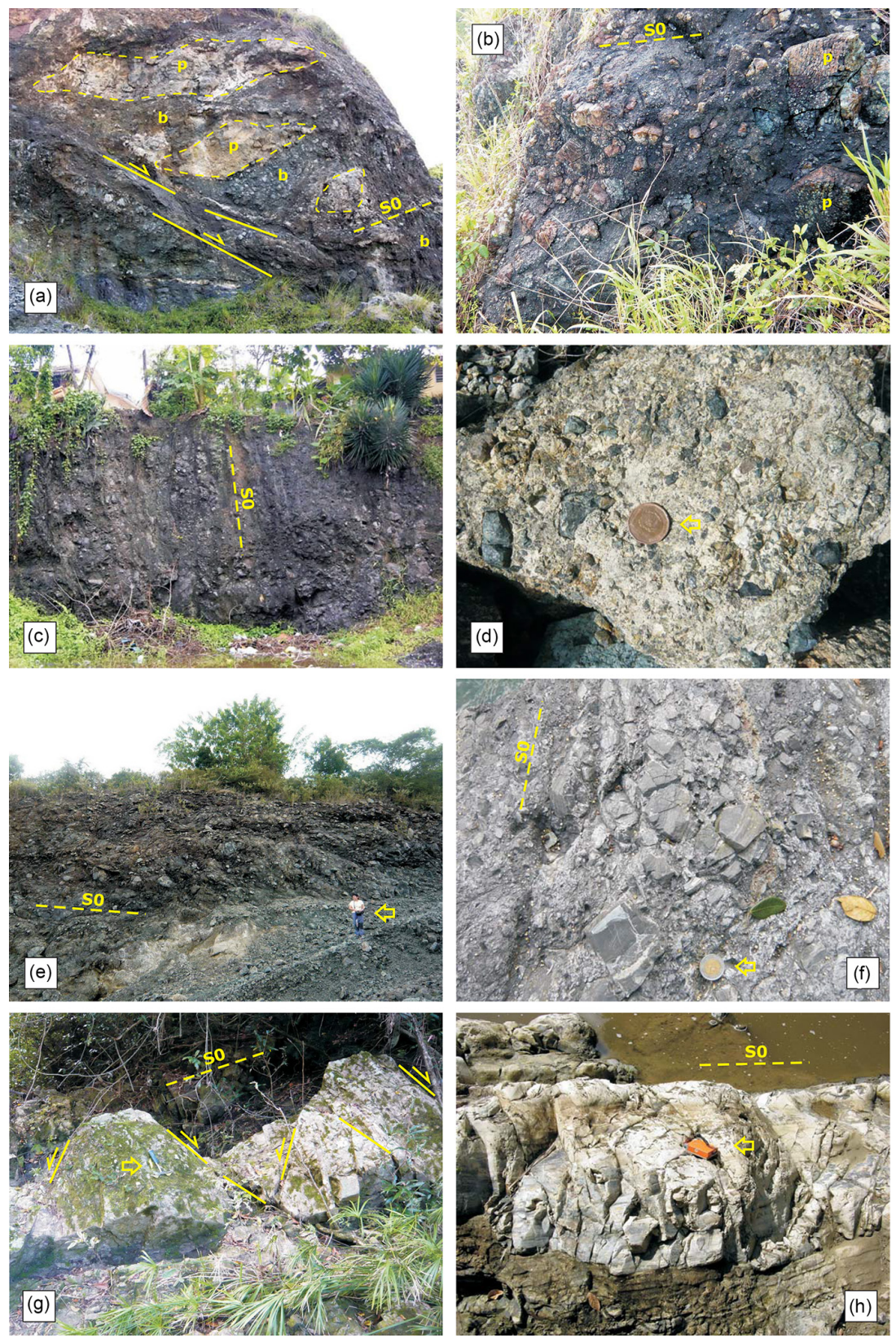

Figure 5. Field photographs of Imbert Fm. (a) Os facies assemblage composed of lensoidal serpentinite blocks in a heterogeneous and faulted matrix composed of breccia, sandstone, and mudstone. Note serpentinized peridotite blocks $(p)$ randomly distributed in a polymictic brecciated matrix (b) and the structureless layers of silts and muds. Angular block attains several metres in size. IM3 unit, Gaspar Hernández section. (b) Gm facies assemblage composed by serpentinite-rich, massive breccia and matrix-supported, muddy-sandy (polymictic) conglomerate. Note the serpentinized peridotite $(p)$ nature of the clast in the breccia. IM3 unit, Loma Seboruco section. (c) Gp facies assemblage composed of clast-supported, sandy (polymictic) breccia and conglomerate. Note inverse-to-normally graded internal structure, dominant clast-supported fabric. Massive internal structure also occurs. Breccia beds are often lenticular with erosive base and interbedded with pebbly conglomerate and coarse-grained sandstone. IM3 unit, Gaspar Hernández section. (d) Detail of matrix-supported breccias of IM3 unit (Gm facies assemblage). Clast shown a random orientation and compositionally are of (mainly) serpentinite, red/green volcanic rocks, laminated sandstone and (rare) white limestone. IM3 unit, Gaspar Hernández section. (e) Gm facies assemblage typical of IM3 unit composed by massive breccia and matrix-supported, muddy-sandy (polymictic) breccia and conglomerate. Note in the breccia body the disorganized internal structure, pebble to cobble size, often erosive base, and random clast orientation of (mainly) serpentinite. (f) Strata disruption by layer-parallel extension in lithified medium thick sandstones controlled by conjugate extensional fractures and pinch-and-swell structures. Note as disrupted layers are fossilized by younger breccia strata. IM2 unit, Río Obispo section. (g) Conjugate sets of normal fault zones deforming the bedding (S0) surfaces of a thick bedded coarse-grained sandstone-laminated mudstone alternating sequence. Note as small faults are fossilized by younger sandstone strata. IM2 unit, Río Obispo section. (h) Tv facies assemblage typical of IM1 unit composed of fine-grained tuff with alternating fine-grained tuffaceous sandstone and mudstone. Río Obispo section. 

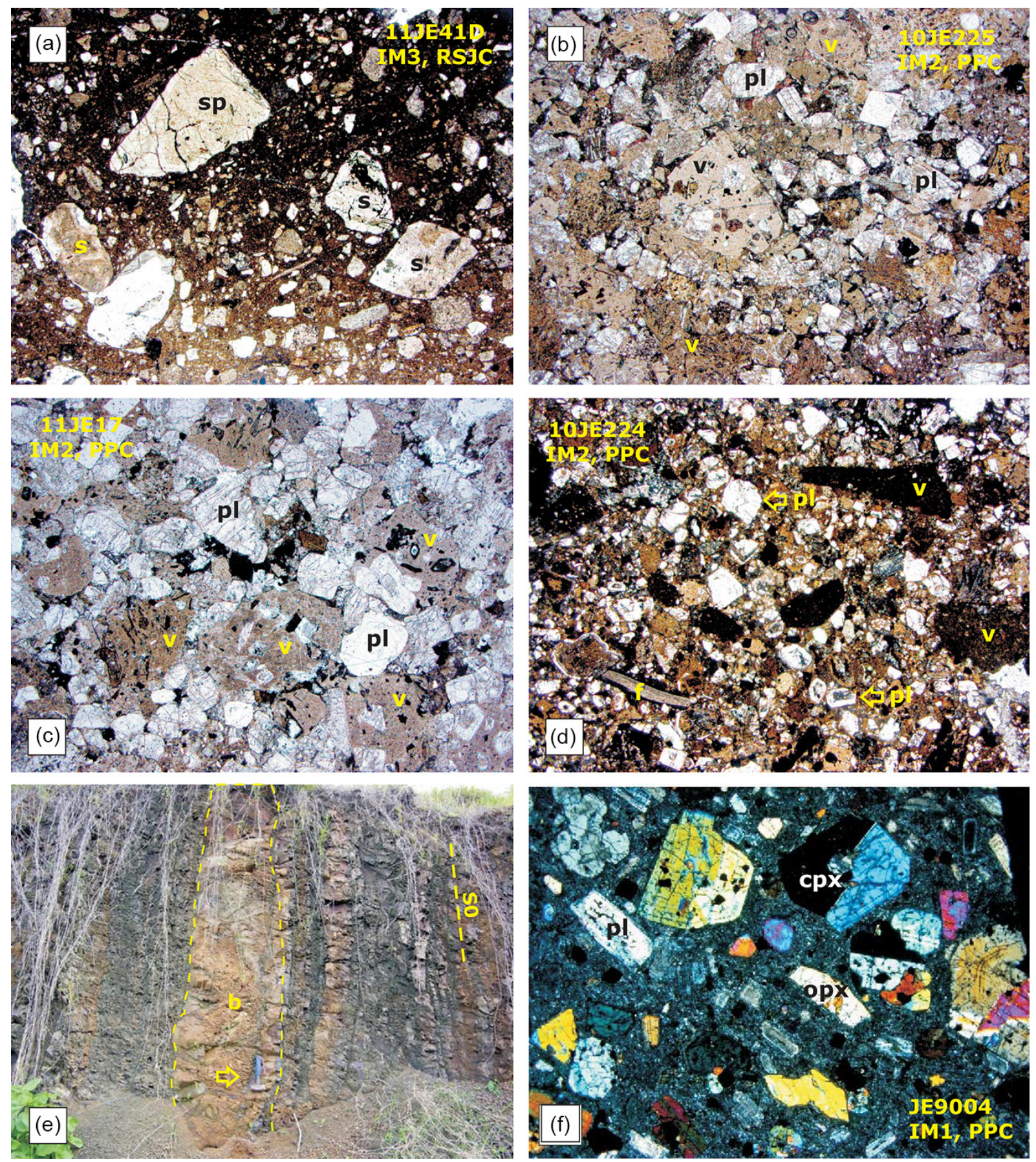

Figure 6. (a-d) Microphotographs (PPL) of the Imbert Fm sandstones and matrix of the breccias consisting of microlitic volcanic rock $(v)$, plagioclase $(\mathrm{pl})$, serpentinized peridotite $(\mathrm{sp})$, serpentinite rock fragments $(s)$, and rare microfossils $(\mathbf{f})$. Volcanic sources of the grains range in composition from basaltic to andesitic. Note the absence of quartz grains. Sandstone grains composition suggest provenance from erosion of volcanic arc and ophiolitic complexes. (e) Basaltic sill intruding an alternance of fine-grained sandstone, siltstone and laminated mudstone of the IM1 unit, Rancho Brugal section. (f) Basalt with microporphyritic textures defined by clinopyroxene (cpx), plagioclase (pl) and orthopyroxene (opx) micro-phenocrysts (XPL).

(ICP-MS) analysis with $\mathrm{LiBO}_{2}$ fusion. The results for selected samples are reported in Supplementary Material B, as well as details of analytical accuracy and reproducibil- ity. Mafic rocks of the Imbert Fm have a narrow $\mathrm{SiO}_{2}$ content, ranging from 52.9 to $55.2 \mathrm{wt} \% \%$ (major oxides recalculated to an anhydrous basis), for relatively low $\mathrm{TiO}_{2}$ con- 
tents between 0.7 and 1.3 wt. \% (Fig. 7). Their low Mg\# values (40-35) indicate that the magmas were extensively fractionated, with exception of one un-fractionated sill in which $\mathrm{Mg} \#=60$ (sample 13JE27). These basalts and basaltic andesites have generally low contents in $\mathrm{CaO}$ (6.7-9.0 wt. \%), for moderately high $\mathrm{Al}_{2} \mathrm{O}_{3}$ (16.1-16.8 wt. \%) and $\mathrm{Fe}_{2} \mathrm{O}_{3 T}$ (9.6-12.2 wt. \%) contents, which increase progressively for decreasing $\mathrm{MgO}$. These trends are tholeiitic and related to the fractionation of olivine plus $\mathrm{Cr}$-spinel, pyroxene, plagioclase and $\mathrm{Fe}$-Ti oxides.

In the $\mathrm{MgO}$ vs. $\mathrm{TiO}_{2}$ diagram of the Fig. 7, volcanic rocks of the Imbert Fm are compared with the volcanic rocks of the Palma Picada complex and the Hbl-diorites of the Curtiembre plutons. They are also compared to the volcanic rocks of the Lower Cretaceous primitive Caribbean island arc of central and eastern Hispaniola, which record a progressive increase in $\mathrm{TiO}_{2}$ contents from the boninites and depleted low-Ti island-arc tholeiites (IAT) to normal IAT and backarc basin basalts (BABB; Escuder-Viruete et al., 2008, 2010), as well as representative Pacific IAT and mid-oceanic ridge basalts (MORB) groups. In terms of $\mathrm{MgO}$ contents, the studied samples of the Palma Picada complex and the Curtiembre plutons range from moderately to highly fractionated, including relatively low- and mid-Ti compositions. Samples of the Imbert Fm and Curtiembre plutons have similar $\mathrm{TiO}_{2}$ contents than the BABB of the Rio Verde complex and the mid-Ti tholeiitic suite of the Mariana Arc-Trough system (Gribble et al., 1998), but lower than the compilation of Pacific MORB (PetDB, 2007). $\mathrm{TiO}_{2}$ contents of the mafic volcanic rocks of the Imbert Fm are higher to those of the IAT, low-Ti IAT, and boninites of the Los Ranchos Fm. However, these rocks are highly fractionated and some samples contain abundant phenocrysts, so they do not provide good estimates of liquid compositions. $\mathrm{TiO}_{2}$ contents in samples of the Palma Picada complex are similar to the IAT and low-Ti IAT groups.

In the $\mathrm{Nb} / \mathrm{Y}$ vs. $\mathrm{Zr} / \mathrm{TiO}_{2}$ immobile trace elements plot of the Fig. 8a, all mafic igneous rocks of the Imbert Fm and Palma Picada complex are subalkalic basalt/andesites and andesites, respectively, and plot within the field of the Caribbean island arc. For these rocks, Ti / V ratios range between 10 and 20, plotting in the subduction-related field (Fig. 8b). Samples of the Palma Picada complex plot in the IAT and low-Ti IAT fields of the Los Ranchos Fm. However, samples of the Imbert Fm and Curtiembre plutons generally plot at higher Ti and $\mathrm{V}$ values, which can be related to the accumulation of $\mathrm{Fe}-\mathrm{Ti}$ phases in these highly fractionated magmas. In a MORB-normalized multi-element plot (Fig. 8; data normalization from Sun and McDonough, 1989), the volcanic rocks of the Imbert Fm have light rare earth elements (LREE) enriched $\left([\mathrm{La} / \mathrm{Nd}]_{\mathrm{N}}=1.4-1.8\right)$ and slight heavy rare earth elements (HREE) depleted $\left([\mathrm{Sm} / \mathrm{Yb}]_{\mathrm{N}}=\right.$ 0.8-1.8) patterns, with low $\mathrm{Nb}$ contents (1.7-2.5 ppm). They exhibit positive $\mathrm{Ba}, \mathrm{U}, \mathrm{K}$, and $\mathrm{Pb}$ spikes, and negative $\mathrm{Nb}-$ $\mathrm{Ta}$ (and $\mathrm{Ti}$ ) anomalies, typical of subduction-related rocks
(Pearce and Peate, 1995). These patterns and the values of the trace element ratios $\mathrm{Ti} / \mathrm{V} \leq 20, \mathrm{Zr} / \mathrm{Nb}<5$ and $\mathrm{Zr} / \mathrm{Nb}>10$, are characteristic of IAT magmas (e.g. Pearce and Peate, 2005). In this sense, their patterns are very similar to the IAT of the Los Ranchos Fm (Escuder-Viruete et al., 2006, 2010). The low $\mathrm{TiO} 2$ content and $(\mathrm{Sm} / \mathrm{Yb})_{\mathrm{N}}$ ratios suggest that the mantle source of these mafic magmas was depleted and did not contain garnet.

In the Palma Picada complex, three compositional groups have been defined (Escuder-Viruete, 2010): normal IAT, lowLREE IAT and calc-alkaline basalts to andesites. These all display a variably LREE enrichment and a flat HREE pattern, with minor $\mathrm{Zr}-\mathrm{Hf}$ but marked negative $\mathrm{Nb}-\mathrm{Ta}$ anomalies (Fig. 8), which also are features typical of subductionrelated magmas. The LREE enrichment, monitorized by the $[\mathrm{La} / \mathrm{Nd}]_{\mathrm{N}}$ ratio, increase from the low-LREE IAT (1.1-1.7), to the IAT (1.5-2.0) and calc-alkaline (2.4-3.1) groups. Respect to the IAT group, the low-LREE group of the Palma Picada complex contains lower absolute abundances of HREE and a more prominent negative $\mathrm{Zr}-\mathrm{Hf}$ anomaly. The LREE depletion, low- $\mathrm{TiO}_{2}$ contents and lower $\mathrm{Ti} / \mathrm{V}$ values, as well as the lower HREE levels, suggest that the mantle source for this group was more depleted than for the IAT group of the Imbert Fm. The calc-alkaline group of the Palma Picada complex is characterized by a higher LILE and LREE enrichment, as well as higher $(\mathrm{La} / \mathrm{Yb})_{\mathrm{N}}$ ratios, suggesting a more "slab" component added to the depleted source (Pearce and Peate, 1995). Samples of the Curtiembre plutons also display a subduction-related trace element pattern and are compositionally similar to the Imbert Fm and the calc-alkaline group of the Palma Picada complex (Fig. 8). The calc-alkaline character of these Hbl-diorites is reinforced by their relatively high $(\mathrm{La} / \mathrm{Yb})_{\mathrm{N}}$ values (Fig. 7f). A calc-alkaline character of the mafic magmas has been related to a more mature evolutionary stage of the Late Cretaceous volcanic arc (i.e. Lewis et al., 2006).

\section{Syn-sedimentary deformation in the Imbert Fm}

The structural evolution of the Imbert Fm can be broken down into three broad stages: (1) pre-collisional, synsedimentary deformation; (2) syn-collisional deformation, which represent the main regional phase in the middle-toupper Eocene, forming inverse faults, thrusts and folds; and (3) post-collisional deformation, which include two generations of faults and folds that show significant contrast in geometry, timing and structural style. This part of the paper focuses on the syn-sedimentary deformation structures, which are well preserved in areas less deformed by the syncollisional tectonic processes.

The bedded successions of the Imbert Fm present evidence for initial disruption occurring prior to and during lithification, as gravitational debris flow, sliding and fragmentation, as well as a continuous process of syn-sedimentary exten- 

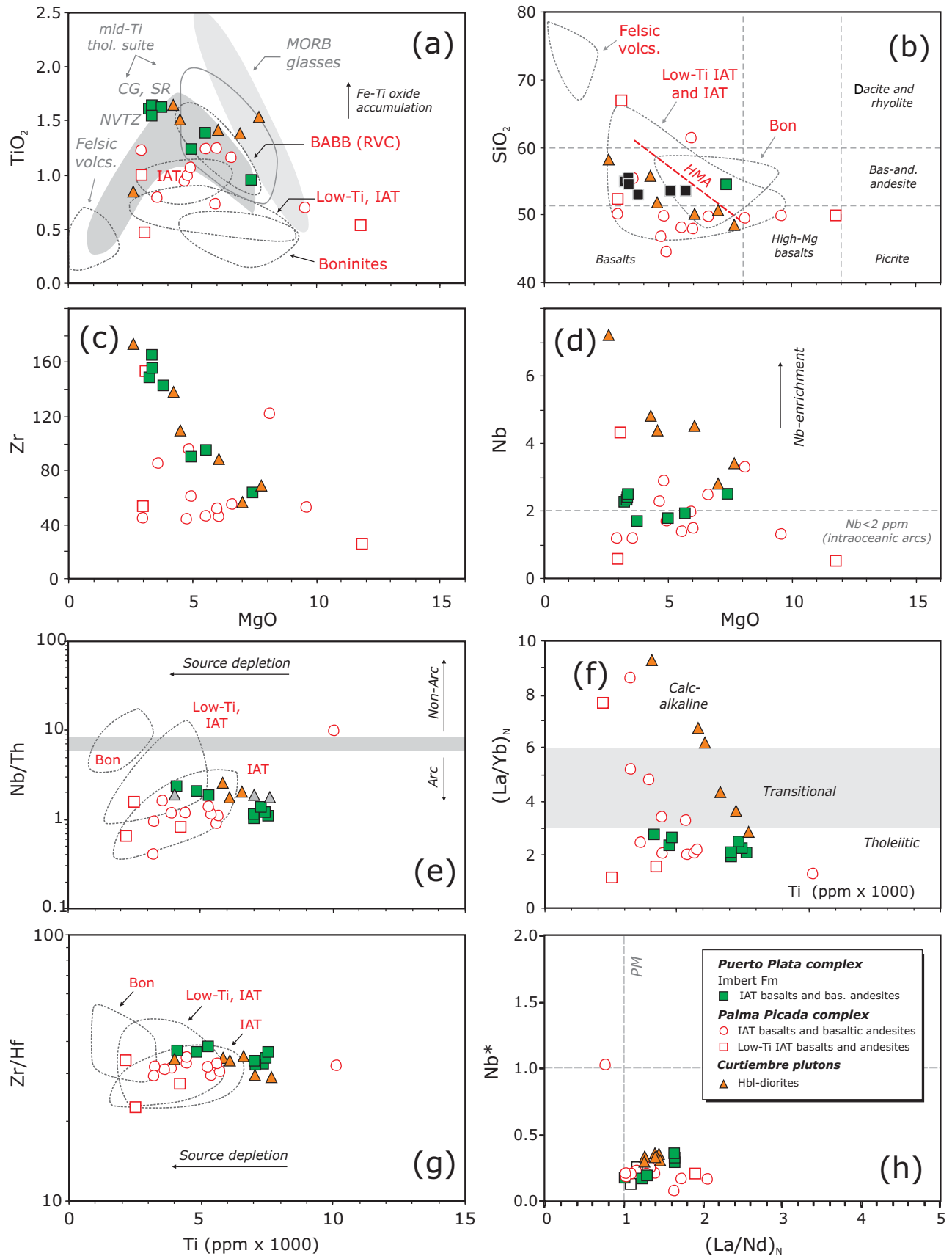

Figure 7. Variation diagrams for rocks from the Imbert Fm, Palma Picada complex and Curtiembre plutons. $\mathrm{MgO}$ vs. $\mathrm{TiO}_{2}$ (a), $\mathrm{SiO}_{2}$ (b), $\mathrm{Zr}$ (c), and Nb (d). NVTZ, CG, and SR fields are respectively for the northern volcano-tectonic zone, the Central Graben and spreading ridge fields of the Mariana Arc-Trough system, which are shown for comparison. MORB glasses are from a Pacific compilation. The different geochemical groups of Lower Cretaceous igneous rocks in Hispaniola are the following: IAT, normal island-arc tholeiites; low-Ti IAT, low$\mathrm{Ti}$, and LREE-depleted island-arc tholeiites; Bon, boninites; and felsic volcanic rocks and tonalites. Ti vs. $\mathrm{Nb} / \mathrm{Th}(\mathbf{e}),(\mathrm{La} / \mathrm{Yb})_{\mathrm{N}}(\mathbf{f})$, and $\mathrm{Zr}$,/ $\mathrm{Hf}(\mathbf{g})$, and $(\mathrm{La} / \mathrm{Nd})_{\mathrm{N}}$ vs. $\mathrm{Nb}^{*}(\mathbf{h})$ diagrams are for rocks from the same lithological units. See text for explanation.

sional faulting (see below). The resulting chaotic rock assemblages are characterized by clasts and blocks dispersed in a detrital matrix produced by disaggregation and new deposition. Therefore, formation of a clastic fabric indicates that the mixing processes are of sedimentary nature. In the
Loma Seboruco section of the PPC, the breccia deposits include angular and sub-rounded blocks of ophiolitic lithologies, up to $0.5 \mathrm{~m}$ long, floating with a random distribution in the polymictic micro-conglomerate to sandstone-size matrix (Fig. 5d). In the Gaspar Hernández section of the RSJC, 

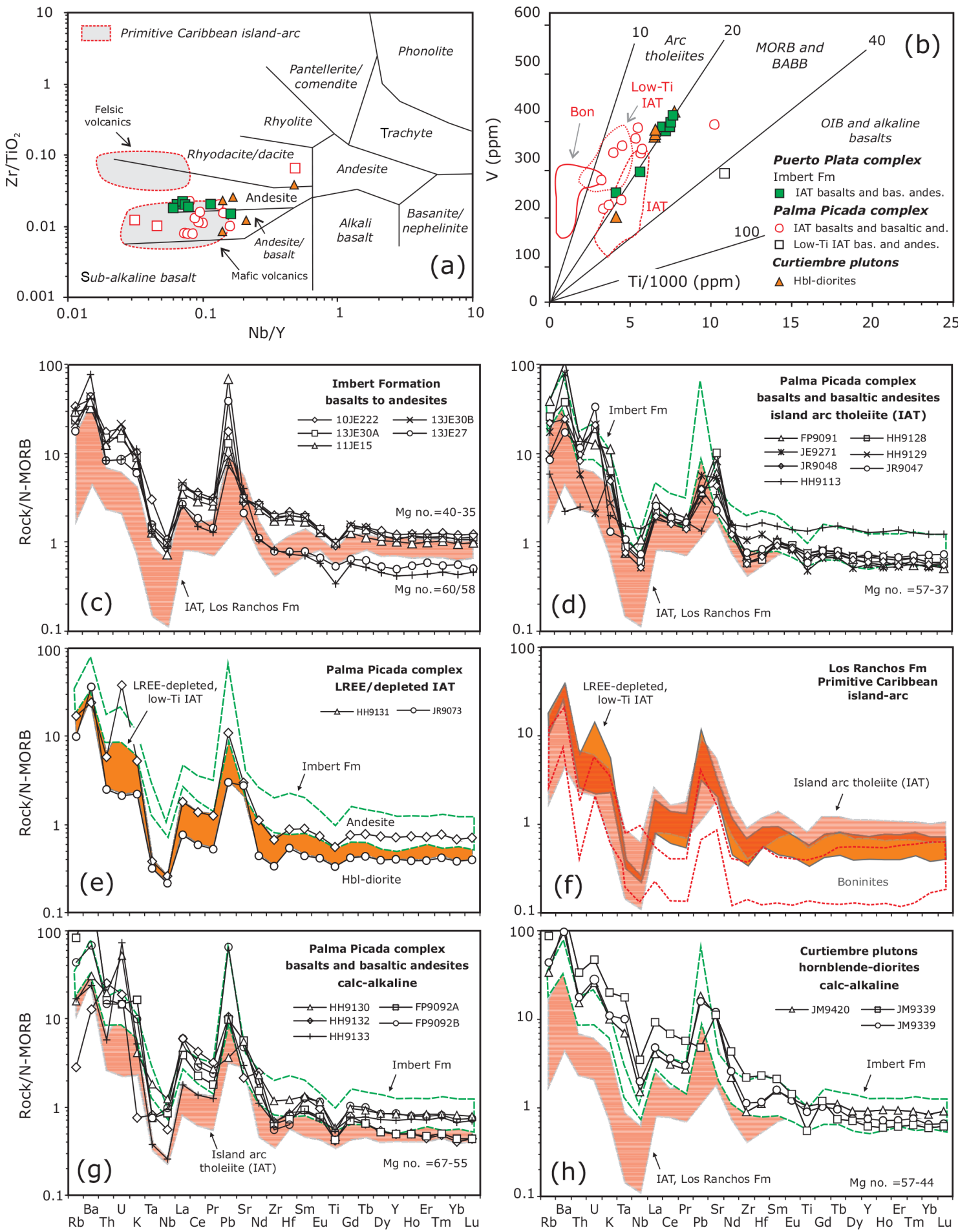

Figure 8. (a) $\mathrm{Nb} / \mathrm{Y}$ vs. $\mathrm{Zr} / \mathrm{TiO}_{2}$ diagram and (b) $\mathrm{Ti}-\mathrm{V}$ diagram for rocks from the Imbert Fm, Palma Picada complex, and Curtiembre plutons. MORB-normalized extended trace-element plots for volcanic rocks of the (c) Imbert Fm, (d, e, g) Palma Picada complex, and (h) Curtiembre plutons. The diverse geochemical groups of Lower Cretaceous igneous rocks in Hispaniola shown in (f) are (Escuder-Viruete et al., 2006, 2010): IAT, normal island-arc tholeiites; low-Ti IAT, LREE-depleted island-arc tholeiites; and Bon, boninites. See text for explanation. 
large blocks of serpentinized peridotites represent slipped blocks (up to $30 \mathrm{~m}$ in size; Fig. 5a). The matrix is devoid of sedimentary structures, except for locally developed finingupward grading. The breccia alternate locally with laminated to massive sandstone and mudstone, indicating turbiditic deposition in a deep-marine sedimentary environment. Synsedimentary faulting produces discontinuous structures in the Imbert Fm that are spatially limited and generally not accompanied by an extensive strata disruption or a block-in-matrix style of deformation. They consist of conjugate sets of extensional shear fractures and small faults, "en-échelon" vein systems, cataclastic fault rocks, local symmetric and asymmetric pinch-and-swell and boudinage structures, as well as very rare folds. Syn-sedimentary folds have metric amplitudes and are disharmonic, close to isoclinal, and asymmetric with vergence toward the NE and SW. Locally NW-SE hinge lines are present. Folds can occur associated with small normal detachments that display a coherent NE and SE-directed sense of normal movement. All these structures are not pervasively developed and characterize the IM2 and, particularly, the IM3 units.

The stress regime prevailing in the depositional setting can be deduced from the syn-sedimentary deformation structures. In the PPC, the debris flow and turbiditic deposits of the Imbert Fm are affected by WNW-ESE to NW-SE and WSW-ENE to W-E trending joints and small faults (Fig. 4b), which generally present a high angle of dip $\left(>70^{\circ}\right)$. In the RSJC, the debris flows are deformed by W-E to WNW-ESE and NNW-SSE to NNE-SSW trending small faults (Fig. 4d), that have a mid- to high angle of dip $\left(>30^{\circ}\right)$. According to the geometry of the fracture system, they can be classified as hybrid (combined tensional and shear) with two joint sets forming an angle $<60^{\circ}$, or shear, organized by two joint or small fault sets with an angle about $60^{\circ}$. As new turbiditic strata seal the hybrid joints and the half-graben structures developed by the movement of the faults, these structures are temporally syn-sedimentary (Fig. $5 \mathrm{~g}$ ). However, to know the original geometry of these structures and to deduce the synsedimentary stress regime, they must be restored to the horizontal. Unfolding of the bedding at each station made this correction and results are shown in Fig. 9.

In each station, the corrected orientations of shear and hybrid joints are distributed in two conjugate sets, which generally have high angles of dip $\left(>60^{\circ}\right)$. The more frequent trends are WNW-ESE to NW-SE, W-E to WSW-ENE, and SWNE. The associated small faults are organized in two similar conjugate sets in each station, which present opposite normal sense of movement. The joints and small faults developed in the gabbros and peridotites of the PPC also record these main trends. The restored normal sense of fault movement generally has a minor oblique slip component, developing graben and semi-graben structures up to several metres wide. The maximum vertical slip range from several centimetres to few metres. In occasions, the fault planes are gently striated, showing slickensides that enable kinematic interpretation. In several stations, the restored geometry of the brittle structures that affect the sedimentary rocks indicates a general subvertical compression and a NNE-SSW to NE-SW trend of subhorizontal extension (Fig. 9). In the PPC, a NW-SE trend of subhorizontal extension is also locally recorded.

More precise information about the syn-sedimentary stress can be obtained from the palaeostress analysis of the small brittle structures. The palaeostress analysis allows to establish the main stress axis direction and the axial ratio (shape) $R=\left(\sigma_{2}-\sigma_{3}\right) /\left(\sigma_{1}-\sigma_{3}\right)$ of the stress ellipsoid. For this analysis the FaultKin software (Marrett and Almendinger, 1990) was used in nine outcrops of the Imbert Fm (Suplement C). The results were interpreted in combination with other types of data with kinematic significance, such as conjugate shear fractures, tension fractures, and calcite-filled tension gashes.

\section{Ar-Ar geochronological data}

The main objective of Ar-Ar geochronology was to obtain age constraints for the exhumation of the ophiolitic basement of the PPC, source of the rock fragments found in the Imbert Fm. For this goal, three samples were taken: two gabbros from the ophiolitic substrate and other gabbroic clast from the breccias of the overlying IM3 unit. Sample locations are shown in Fig. 2. Analytical procedures and results are reported in the Suplement D. All ages are quoted at the $2 \sigma$ level of uncertainty. Geologic time scale is from Gradstein et al. (2012).

Sample 10JE54 is a coarse-grained leucogabbro from the PPC, collected in a quarry on the road Puerto Plata, Imbert. Under the microscope, it displays a layered adcumulate igneous texture, defined by variations in modal contents of plagioclase and clinopyroxene, with minor orthopyroxene, olivine and spinel. The obtained plagioclase plateau age is $44.0 \pm 3.1 \mathrm{Ma}(\mathrm{MSWD}=1.2)$ for seven steps $(1-7)$ and $100.0 \%$ of the ${ }^{39}$ Ar released (Fig. 10a). The inverse isochron age on these seven points is $42.8 \pm 5.3 \mathrm{Ma}(\mathrm{MSWD}=1.5)$, with an initial ${ }^{40} \mathrm{Ar}-{ }^{36} \mathrm{Ar}$ intercept at $350 \pm 20$. The inverse isochron has high initial ${ }^{40} \mathrm{Ar}-{ }^{36} \mathrm{Ar}$ argon ratios, indicating the presence of trapped argon with a composition differing from that of atmospheric argon. The isochron age is considered as the best age of the sample, which is similar to the plateau age within error. Sample JM9112 is a coarse-grained leucogabbronorite from the PPC, collected at the same quarry that sample 10JE54. It contains plagioclase, clinopyroxene and orthopyroxene, with minor olivine and spinel. The obtained plagioclase plateau age is $35.1 \pm 8.1 \mathrm{Ma}(\mathrm{MSWD}=4.6)$ for eight steps $(3-10)$ and $96.0 \%$ of the ${ }^{39} \mathrm{Ar}$ released (Fig. 10b). The inverse isochron age is $34 \pm 13 \mathrm{Ma}$ (MSWD = 3.8), with an initial ${ }^{40} \mathrm{Ar}-{ }^{36} \mathrm{Ar}$ intercept at $300 \pm 18$. As the inverse isochron ${ }^{40} \mathrm{Ar} /{ }^{36} \mathrm{Ar}$ intercepts equivalent to the atmosphere (295.5), the plateau age is the best estimated age for the sample in spite of its high uncertainty. Sample HH9124 is a block of coarse-grained troc- 
Restored orientational data of sync-sedimentary deformations
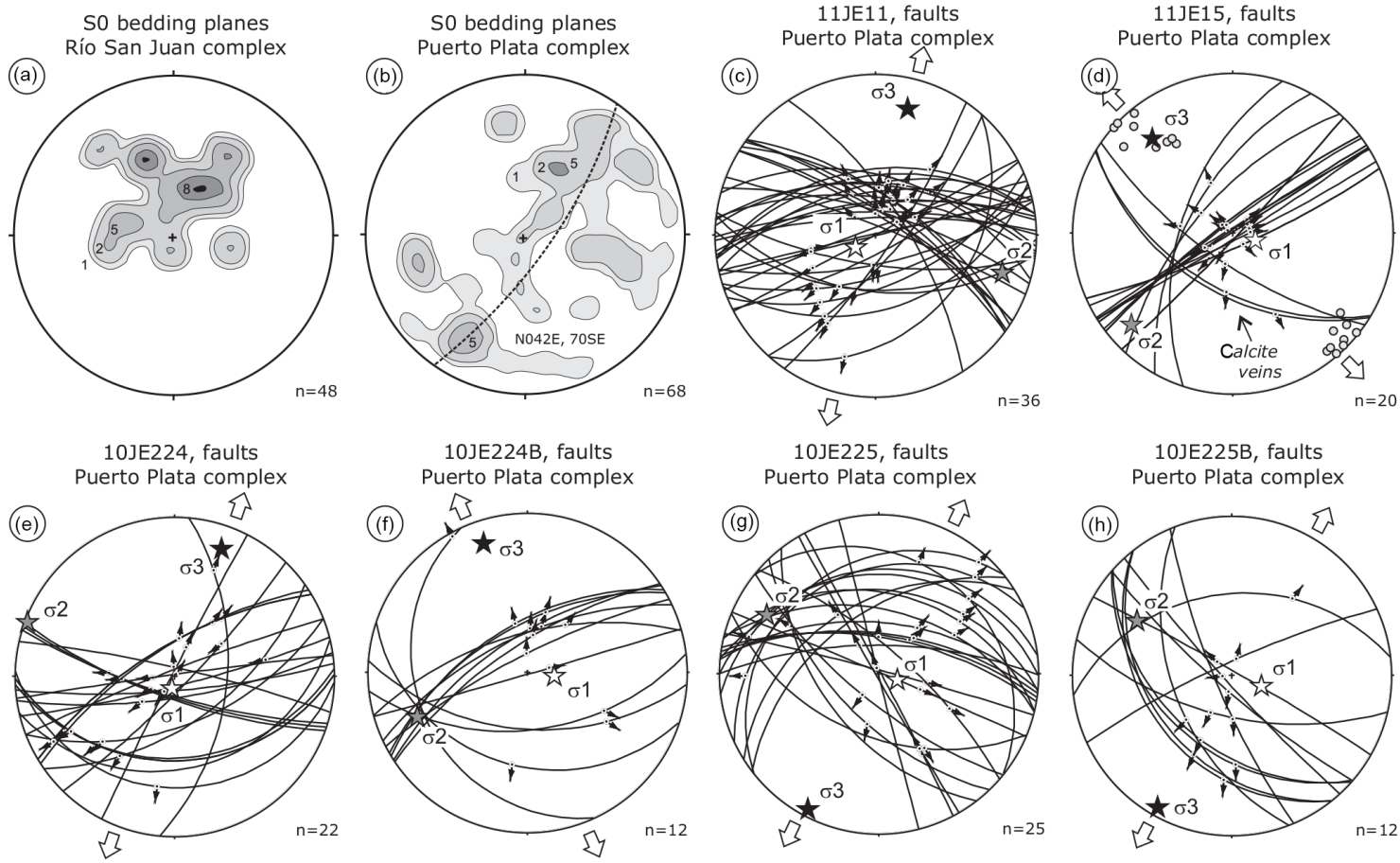

10JE225, faults

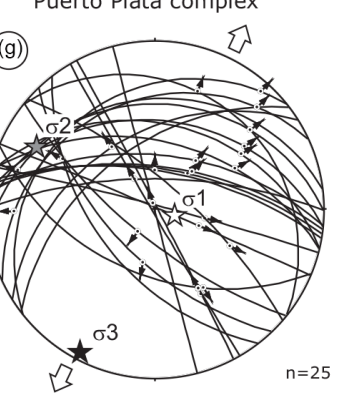

10JE225B, faults Puerto Plata complex

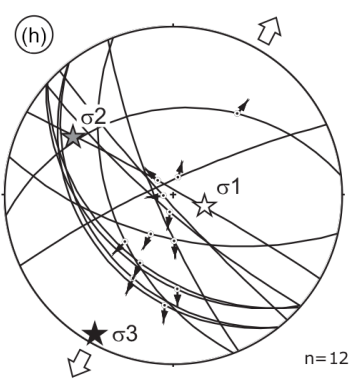

10JE252, faults
Río San Juan complex

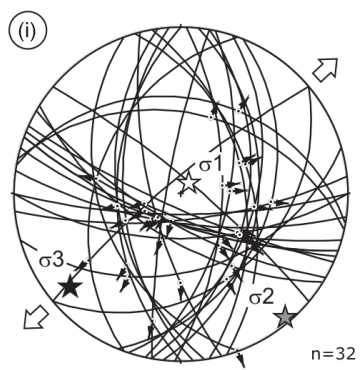

10JE252B, faults

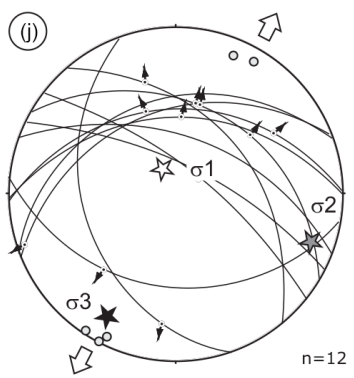

11JE51, faults
Río San Juan complex

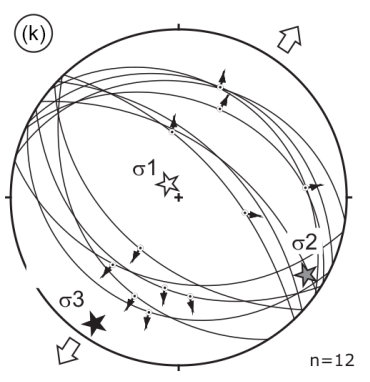

11JE51, faults
Río San Juan complex
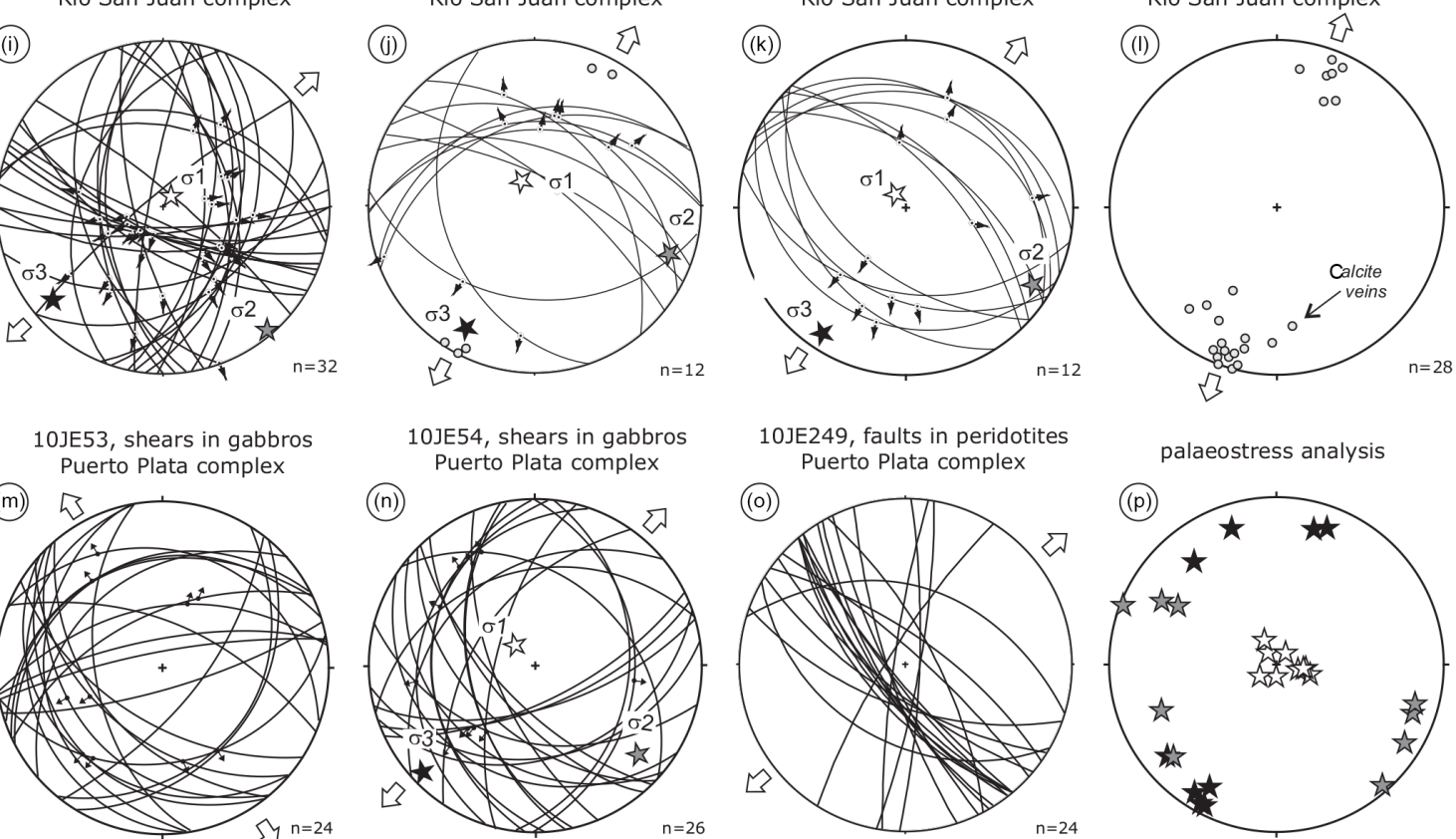

10JE54, shears in gabbros
Puerto Plata complex

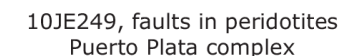

(n))

(0))

palaeostress analysis
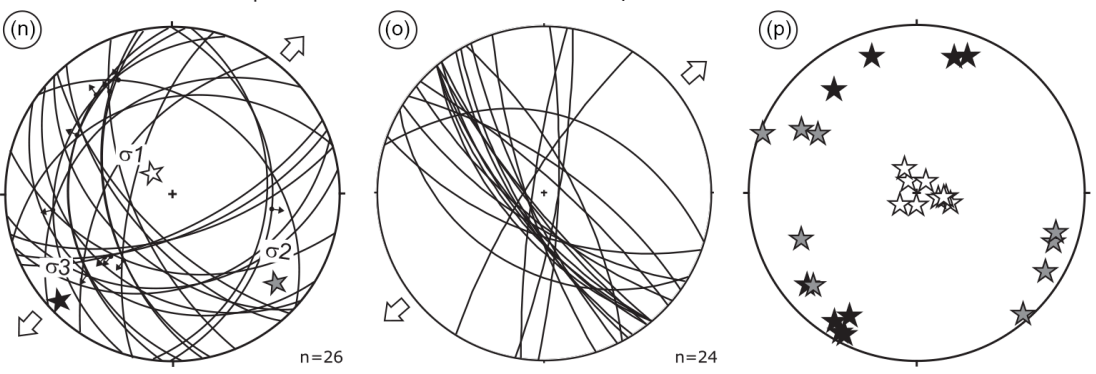

- Pole of vein plane

stress axes:

$\longrightarrow$ Fault plane with slikenside indication

$\leftrightarrow \Rightarrow$ Trend of extension axis

is $\sigma_{1} \star \sigma_{2} \star \sigma_{3}$

Figure 9. (a, b) Stereoplots of bedding planes (S0) of the Imbert Fm in the Puerto Plata and Río San Juan complexes. (c, o) Stereoplots of fault, joints and calcite veins affecting Imbert Fm deposits from several measurement stations at Puerto Plata and Río San Juan areas. The upper number indicates the station. (p) Stereoplot of stress-axes in all stations. Stereoplots also include the stress-axes obtained from the palaeostress analysis. The white arrows indicate the trend of subhorizontal extension. Equal angle, lower hemisphere projection. 
tolite from the IM3 unit of the Imbert Fm, collected in the Arroyo Seco outcrop at the Cerro de Gran Diablo. It contains igneous plagioclase and olivine, with minor ortho and clinopyroxene, and secondary hornblende. The obtained hornblende plateau age is $55.0 \pm 8.1 \mathrm{Ma}(\mathrm{MSWD}=0.1)$ for six steps $(2-$ 7) and $69.9 \%$ of the ${ }^{39} \mathrm{Ar}$ released (Fig. 10c). The inverse isochron age is $55.5 \pm 9.6 \mathrm{Ma}(\mathrm{MSWD}=0.1)$, with an initial ${ }^{40} \mathrm{Ar}-{ }^{36} \mathrm{Ar}$ intercept at $294.1 \pm 9.2$. The sample yielded release spectra with plateau and inverse isochron ${ }^{40} \mathrm{Ar} /{ }^{36} \mathrm{Ar}$ intercepts equivalent to the atmosphere (295.5), and therefore the plateau age is the best estimated age for the sample in spite of its high uncertainty.

\section{Discussion}

\subsection{A Caribbean supra-subduction zone setting for the Imbert Fm volcanism}

Geochemical data show that the mafic volcanic rocks within the Imbert Fm present typical subduction-related features (e.g. Pearce and Peate, 1995): LILE (large-ion lithophile elements) are enriched relative to LREE, and both element groups are enriched relative to high field strength elements (HFSE), giving the characteristic negative $\mathrm{Nb}-\mathrm{Ta}$ anomalies (Fig. 8). These rocks are interbedded with, and intrude to, the fine-grained rocks of the IM1 lower unit, which also intercalate distal tephra fallout deposits. Therefore, these sedimentary rocks were deposited in a supra-subduction zone setting with ongoing arc-volcanic activity, more probably at the deep-water area of the forearc (e.g. Draut and Clift, 2012). Coeval related volcanic rocks are the tholeiitic and calc-alkaline basalts to andesites of the Palma Picada complex and the Hbl- diorites of the Curtiembre plutons, which also recorded a SSZ magmatism, probably more closely to the volcanic front. The arc-like geochemical similarity between the mafic volcanic rocks of the Imbert Fm and the Palma Picada complex, support the interpretation that the lower Eocene igneous rocks of the Septentrional Cordillera records the latest volcanic activity of the Caribbean island arc. On the other hand, these volcanic rocks are geochemically comparable to the upper Maastrichtian to lower Paleocene mafic plutonic rocks of the Curtiembre, which also implies that this latest arc-like magmatism was also recorded in the Cordillera Oriental of Hispaniola. As it has been recently suggested, both lithotectonic domains belong to the Caribbean plate (Escuder-Viruete et al., 2014).

\subsection{Regional lithological correlations and implications}

The stratigraphic columns for the Imbert Fm are synthesized in Fig. 11, which also illustrates the inferred lithological correlations and lateral facies variations between different sections. The figure shows that the IM1 unit is essentially made up of thin to medium-bedded sandstones and mudstones, interbedded with fine-grained volcanic rocks, that can form sections several hundreds of metres thick (El Puerto section, PPC), but that can also be entirely absent (RSJC) due to erosion or non-deposition. These rocks are interpreted as result of dilute turbidity currents, hemipelagic sedimentation, and volcanic particle fall in a deep-water, forearc depositional environment. Evidence of coeval synsedimentary tectonics are absent. The IM2 unit is a typical turbiditic sequence composed of alternating coarse-grained sandstones and mudstones, which have been deformed by syn-sedimentary extensional faulting. These deposits are interpreted as result of high-concentrated turbidity currents in a proximal submarine fan and/or channel-fill setting, affected by syn- to post-depositional slumping or sliding processes. The IM3 unit is a variably thick, olistostromic (chaotic) unit, composed of serpentinite-rich polymictic breccias, conglomerates and sandstones. The matrix- and clast-supported breccias are mainly interpreted as product of gravity-driven mass-transport processes (non-cohesive debris flows, debris avalanches, slumps and block slides) in a slope setting, or subaqueous fault scarp. The mesoscopic structures of boudinage, pinch-and-swell and slumping are interpreted as result of layer-parallel extension related to submarine sliding. The serpentinite-rich debris flows, typical of the IM3 unit, are indicative of mobilization of hydrated ultramafic rocks, as those of the underlying PPC and RSJC.

Figure 11 also shown that the IM3 unit unconformably overlies different tectonostratigraphic units in the RSJC (serpentinites at the Gaspar Hernández section and a metamorphic mélange with high-P blocks at the other sections), indicating clearly that its lower contact is an erosional surface, over an already structured subduction-accretionary prism. In the PPC, the lower stratigraphic contact of the Imbert Fm does not outcrop, but clasts in the breccias are of serpentinized peridotites, gabbroic rocks and basaltic extrusives, typical of the underlying complex, which suggest that the Imbert Fm unconformably overlies the SSZ ophiolite. Therefore, depositional facies, bed thickness and grain size in the Imbert Fm define a large-scale, coarsening-upward sequence, developed between two unconformity surfaces (E1 and E2 in Fig. 11). However, an intra-formational unconformity between IM 2 and IM 3 units cannot be ruled out. In the PPC sections, distal turbidites and hemipelagic mudstones, radiolarites and coeval arc-related volcanism, pass upwards into a more proximal turbiditic sequence and to ophiolitederived breccias and conglomerates. Some of the ophiolitederived conglomerates include sub-rounded serpentinite and basalt clasts suggestive of a high-energy, more shallow-water setting. This evolution indicates sediment accumulation in a progressively shallower, marine palaeoenvironment. Also, the Imbert Fm is affected by syn-sedimentary, small-scale, high-angle faults in the IM2 unit, and by low-angle extensional faults and block slides in the IM3 unit. This evolution suggests an increase of the instability upward. The shallowing and the increase instability in the basin are interpreted as a response to uplift, erosion and/or tectonic denudation of the 

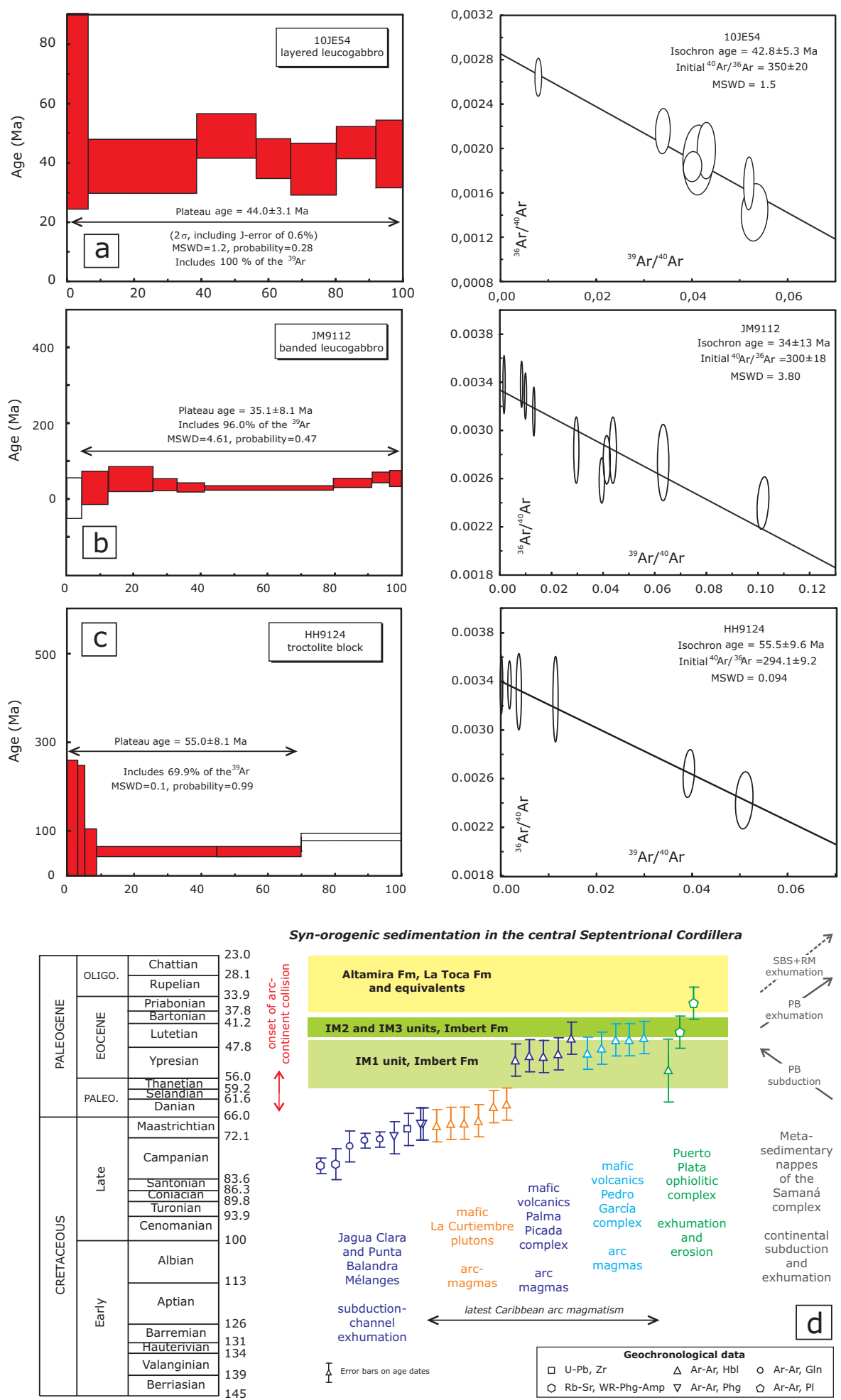

Figure 10. $(\mathbf{a}, \mathbf{b}, \mathbf{c}){ }^{40} \mathrm{Ar} /{ }^{39} \mathrm{Ar}$ spectrum and isochron diagrams of plagioclase from leucogabbros of the Puerto Plata ophiolitic complex and of hornblende from a troctolite block in the Imbert Fm. Analytical procedures are described in Escuder-Viruete et al. (2014). A summary of ${ }^{40} \mathrm{Ar}-{ }^{39} \mathrm{Ar}$ incremental heating experiments is in Supplementary Material D. Age uncertainties are $2 \sigma$ and include uncertainty in monitor age and decay constant. (d) Temporal relationships between the exhumation of the Jagua Clara mélange (end of oceanic subduction), the latest Caribbean arc magmatism, the exhumation of the SSZ ophiolite, and the sedimentation of the Imbert Fm in the central Septentrional Cordillera, as well as the subduction and exhumation of the Samaná nappes (continental subduction). See text for discussion. 
underlying basement. These processes could be induced by subduction of the North America continental margin and the isostatic rebound of the overlying Caribbean SSZ ophiolite, as in the southern Urals (Brown et al., 2001).

This interpretation agrees with the drastic change of the thickness of the Imbert Fm and the resulting wedge-shaped geometry in cross section for the unit. The wedge-shaped sequence thickens to the $\mathrm{SW}$ in the PPC and pinches out at the RSJC to the NE. This geometry is the result of the seafloor morphology created by the rising of the NE edge of the basin, or outer forearc, with exhumation and erosion of the ophiolitic basement and other underlying units of the accretionary prism, as well as the reworking of the turbiditic and volcanic rocks of the IM1 unit to form debris flow deposits. The breccias were shed from subaqueous scarps created by the uplift and faulting and filled rugged seafloor topography produced over the emplaced ophiolitic thrust sheet. In this sense, palaeocurrent data indicate the existence of a serpentinite source area in the NE.

\subsection{Palaeostress analysis of the syn-sedimentary deformation}

The result of the palaeostress analysis of small fault arrays and joint sets that affect the rocks of the Imbert Fm in selected locations establishes an extensional stress ellipsoid for the syn-sedimentary tectonics in all cases (Fig. 9). These stress ellipsoids are characterized by a subvertical $\sigma_{1}$ axis and a subhorizontal, NNE-SSW to NE-SW $\sigma_{3}$ trending axis. The axial ratios of these ellipsoids are generally high (0.50.9; Suplement C), and indicate a pure to horizontal axially symmetric extension $\left(\sigma_{1} \sim \sigma_{2}\right)$ stress tensor, which is characteristic of pure normal to normal strike-slip deformation. Although most stress ellipsoids show a NE-SW trending $\sigma_{3}$ axis, in some of them (sites 11JE15, 10JE224B and 10JE53), this orientation corresponds to $\sigma_{2}$ probably due to an axis permutation or local perturbations of the regional stress field. The restored syn-sedimentary NW-SE trending normal faults and the metre-scale graben structures that affect the youngest breccia and olistostromic successions of the IM3 unit, such as the 11JE51 and 11JE252 sites, all indicate a general NESW extension. Therefore, a gravity-driven extensional stressfield affects the uppermost levels of the crust during the sedimentation of the Imbert Fm at least in the lower to middle Eocene.

The gravity related tectonics results from instability in the forearc basin. The Imbert Fm records a progressive increase in the syn-sedimentary tectonic activity, culminating in the upper IM3 unit, which include metre to tens of metres-size blocks/olistoliths of variably serpentinized peridotite. These sedimentary relations suggest gravitational collapse associated with submarine sliding as the main disruption mechanism for the generation of the IM3 olistostromic unit, rather that tectonic deformation. After their initial collapse, different types of mass-wasting phenomena, starting from grav- ity sliding and followed by slumping and debris flows, contributed to the final emplacement of the blocks as downslope deposits. The NNE-SSW to NE-SW trend of subhorizontal extension indicates that the sedimentary basin was most probably oriented WNW-ESE to NW-SE (actual coordinates). The sub-perpendicular trends of palaeocurrent and sliding directions (Figs. 3, 4) are also consistent with this orientation for the basin.

\subsection{Age constraints for the Imbert Fm}

${ }^{40} \mathrm{Ar} /{ }^{39} \mathrm{Ar}$ ages reported for the gabbroic rocks of the PPC are presumed to be amphibole and plagioclase-cooling ages because all of the dates are from plutonic rocks with high crystallization temperatures. Therefore, the ${ }^{40} \mathrm{Ar} /{ }^{39} \mathrm{Ar}$ plateau ages of $44.0 \pm 3.1 \mathrm{Ma}$ and $35.1 \pm 8.1 \mathrm{Ma}$ obtained in plagioclase from the gabbros suggests cooling of the PPC at $\sim 45-40 \mathrm{Ma}$ (middle Eocene), due the assumed closure temperature of plagioclase $\left(200-235^{\circ} \mathrm{C}\right)$. In spite of its high uncertainty, the ${ }^{40} \mathrm{Ar} /{ }^{39} \mathrm{Ar}$ plateau age obtained for hornblende in a block from the IM3 unit of the Imbert Fm also indicate a cooling at $T<500 \pm 50^{\circ} \mathrm{C}$ (closure temperature of amphibole) in the lower-to-middle Eocene.

This range of $\mathrm{Ar}-\mathrm{Ar}$ ages indicates the following: (1) exhumation and cooling at rates of $\sim 30^{\circ} \mathrm{C} \mathrm{Ma}^{-1}$ of the ophiolitic PPC during the lower-to-middle Eocene; (2) erosion of this complex, which is the source of the ophiolitic fragments in the Imbert Fm; and (3) the coeval sedimentation of the Imbert Fm (IM2 and IM3), which is also indicated by its Paleocene/lower Eocene palaeontological age in the PPC (Pindell and Draper, 1991; Monthel, 2010;) and RSJC (Draper and Nagle, 1991; Escuder-Viruete, 2009) complexes. These relationships also imply the uplift to the surface of the SSZ ophiolite during of shortly after the emplacement of the intra-oceanic Caribbean island arc onto the North America continental margin.

Figure 10d includes temporal relationships between the exhumation of the Jagua Clara mélange (end of oceanic subduction), the latest Caribbean arc magmatism, the exhumation of the SSZ ophiolite, and onset of syn-orogenic sedimentation in the central Septentrional Cordillera, as well as the continental subduction and exhumation of the Samaná nappes. In the RSJC, the final juxtaposition of the arc terrains onto the Jagua Clara mélange along the Morrito fault zone, took place in the latest Maastrichtian to Paleocene, at the onset of the arc-continent collision (Escuder-Viruete et al., 2013a). As these units form the basement over which the breccias of the upper IM3 unit of the Imbert Fm were deposited, this stratigraphic relationship implying a lower age limit of $\sim 60 \mathrm{Ma}$ (lower Paleocene) for the Imbert Fm. Also, this juxtaposition of arc- and oceanic-derived terrains is coeval with the onset at $60 \pm 5 \mathrm{Ma}$ of the prograde high-P metamorphism in the metasedimentary nappes of the Samaná complex (Escuder-Viruete et al., 2011b). Interestingly, a regionally consistent top-to-the-NE/ENE tectonic transport 


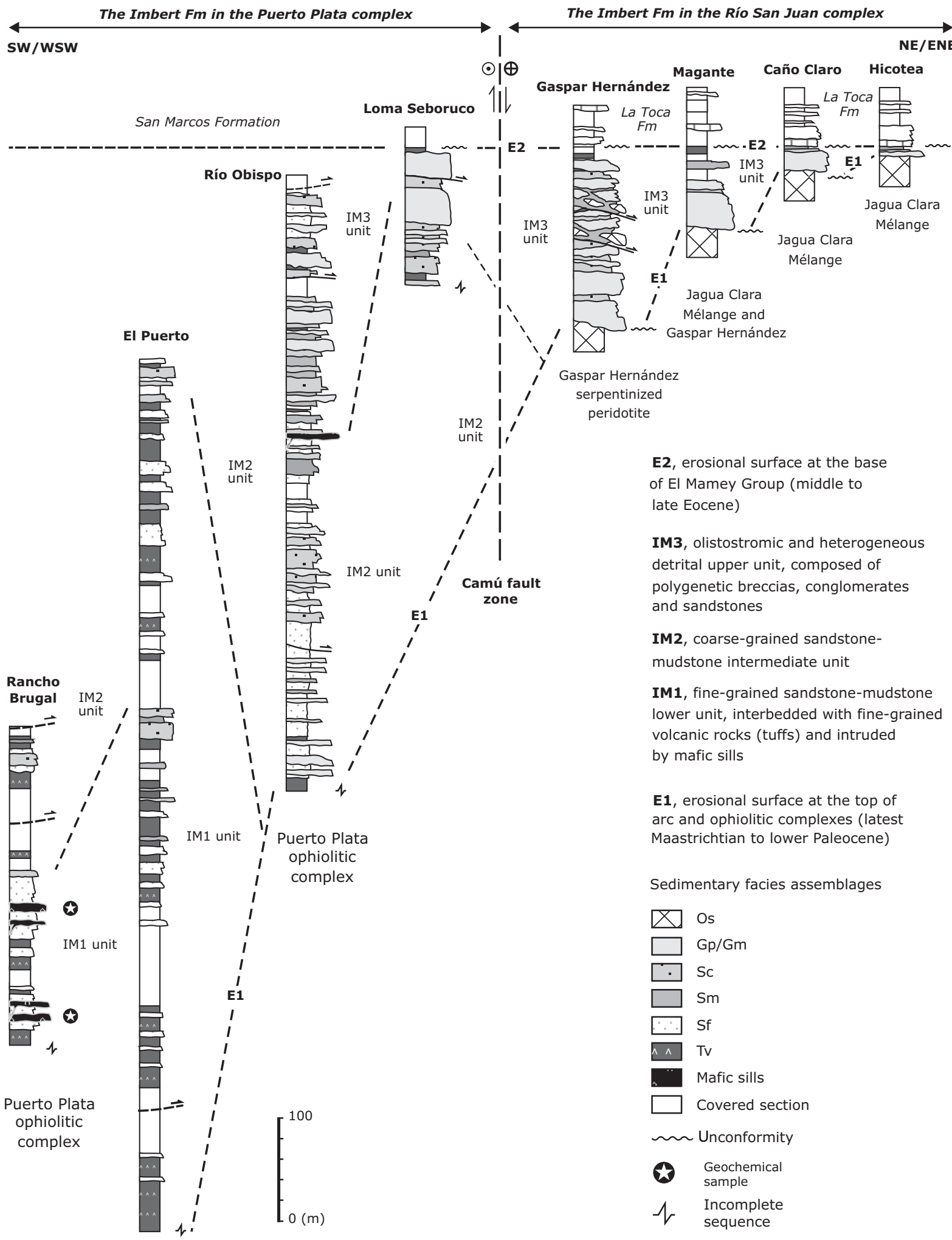

Figure 11. Synthetic diagram for the stratigraphy of the Imbert Fm in the Puerto Plata ophiolitic and Río San Juan complexes. See Fig. 2 for locations of sections and text for discussion. 
(a)

SW/WSW

NE/ENE

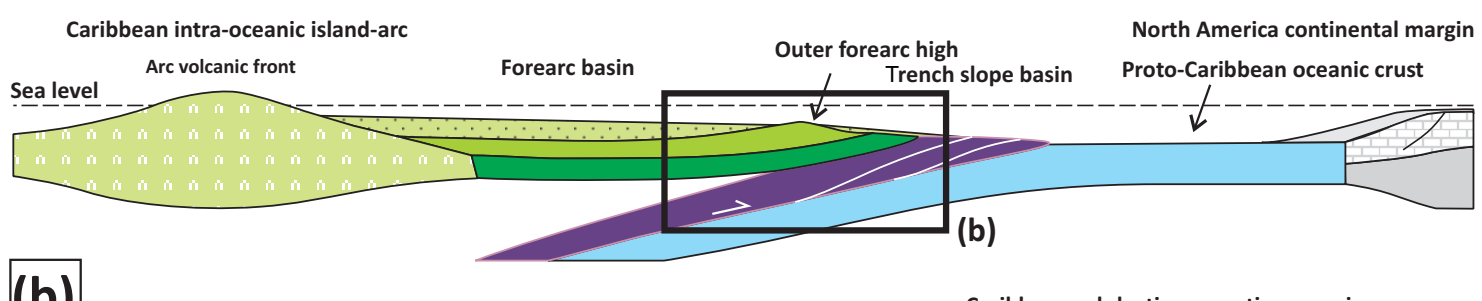

(b)

Caribbean subduction-accretionary prism
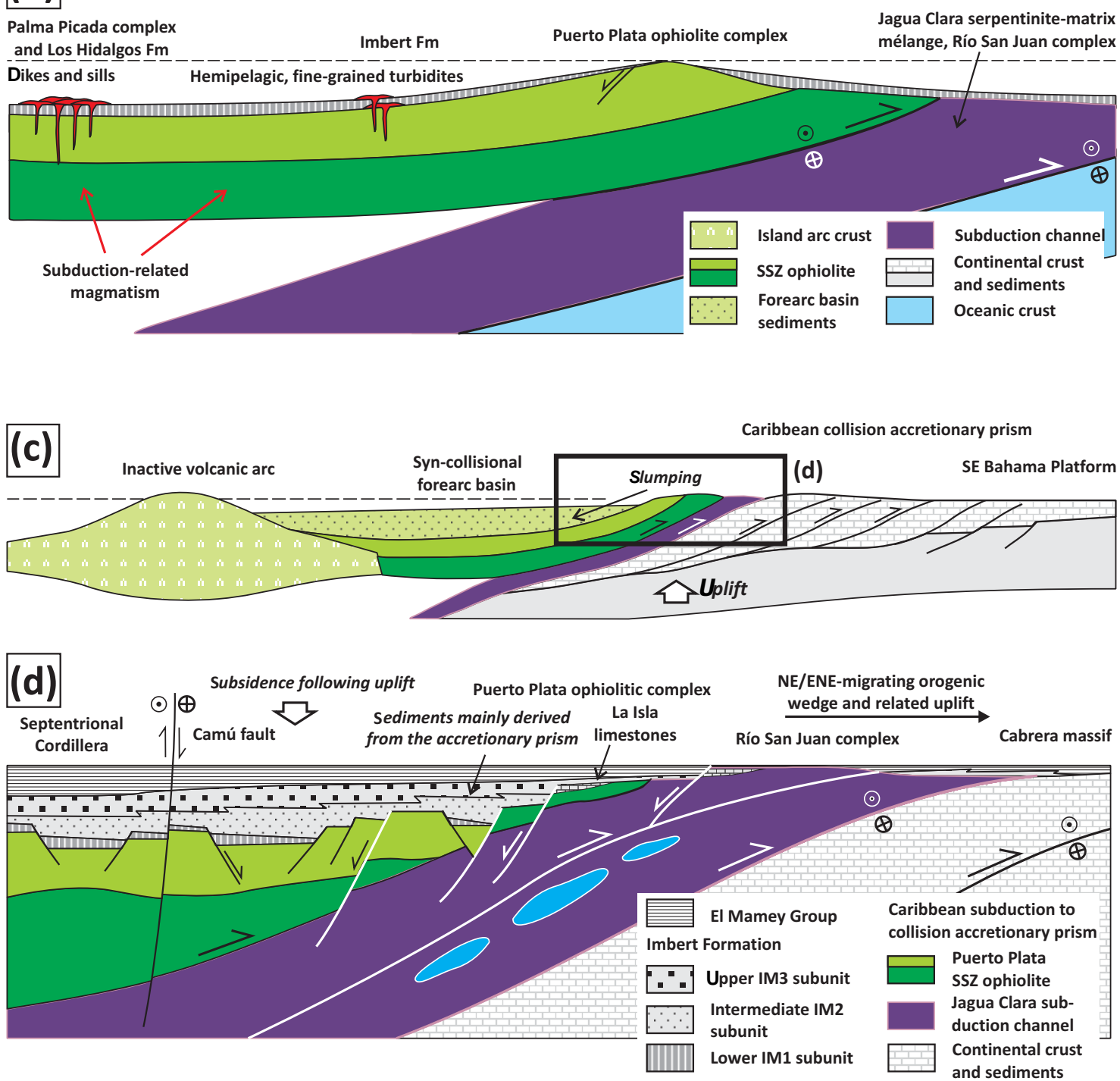

Figure 12. Schematic sedimentary and tectonic evolution of the Imbert Fm and the basal El Mamey Group along the northeastern edge of the pre-collisional forearc $(\mathbf{a}, \mathbf{b})$ and the syn-collisional basin $(\mathbf{c}, \mathbf{d})$ of the northern Caribbean subduction-accretionary prism.

took place in the nappes of the Samaná complex during the Eocene to earliest Miocene (Escuder-Viruete et al., 2011a). This kinematic data indicates that the tectonic incorporation of continental-derived terrains to the developing Caribbean subduction-accretionary prism in a deep crustal level pro- duces a sub-parallel extension at a shallow crustal level, which is a typical process in the dynamics of an accretionary complex (Agard et al., 2009). All sections of the Imbert Fm in the RSJC are unconformably overlain by the La Toca $\mathrm{Fm}$, which contains in the lowermost strata middle-to-upper 
Eocene foraminifera. In summary, the time constraints and stratigraphic relationships establish that the Imbert Fm is upper Paleocene to lower/middle Eocene in age.

\subsection{Tectono-sedimentary evolution}

The tectono-sedimentary evolution recorded in the Imbert Fm comprises three main phases, which are schematically shown in the Fig. 12. The first phase includes the deposition of distal turbidites of the lower IM1 unit in the upper Paleocene to lower Eocene, which are interbedded with volcaniclastic rocks and subduction-related mafic sills and dykes. The arc-like magmatism is also represented by the Palma Picada complex and the Curtiembre plutons. Volcanic rocks are also common in the coeval Los Hidalgos Fm (de Zoeten and Mann, 1999). These relationships imply the presence of a forearc basin in the Paleocene to lower Eocene interval, developed above an ESE-SE-dipping slab of subducted protoCaribbean oceanic crust, and the existence to the SW of an active volcanic arc that constitutes the Hispaniola segment of the intra-oceanic Caribbean island arc. The stratigraphic sections show that the lower contact of the Imbert Fm is depositional and corresponds to an erosional unconformity.

The second phase includes the exhumation and erosion of both ophiolitic and metamorphic rocks of the Caribbean subduction-accretionary prism, whose first appearance as clasts occurs in the serpentinitic breccias of the intermediate IM2 unit. Plagioclase ${ }^{40} \mathrm{Ar} /{ }^{39} \mathrm{Ar}$ dating implies that the cessation of arc volcanism at $48-45 \mathrm{Ma}$ (lower to middle Eocene) was coeval or slightly older than the exhumation of the ophiolite at about 45-40 Ma (middle Eocene). The regional uplift is recorded with the sediment accumulation of the Imbert Fm in a progressively shallower marine palaeoenvironment. Uplift follows with the deposition of the shallow-marine limestones of La Isla Fm in the lower to middle Eocene on top of the exhumed mantle in the PPC. The turbidites of the IM1 unit, the limestones of La Isla Fm, the mafic to ultramafic rocks of the ophiolite and the high$\mathrm{P}$ metamorphic rocks of the subduction channel, were reworked to form the chaotic and debris-flow deposits of the upper IM3 unit. Pebble and cobble-sized fragments were derived from both mantle and crustal levels of the exhumed ophiolite. The angularity of fragments means erosion of a proximal source. Chemical data from the harzburgites and associated boninitic cumulate gabbros imply the highly depleted nature of the PPC ophiolite (Escuder-Viruete et al., 2014), which is a typical feature of SSZ-type ophiolites (e.g. Marchesi et al., 2009). These relationships indicate that breccias and olistostromes formed as culmination of regional uplift and exhumation during the middle Eocene; i.e. during or soon after the latest stages of ophiolite emplacement onto the margin, still in a subaqueous setting. This regional uplift is related to an isostatic response induced by the underplating of (low-density) continental material during the arc-continent collision (Fig. 12). These features are consis- tent with deformation and sedimentation processes that occurred at shallow crustal levels in a basin, located at the top of an advancing accretionary wedge (e.g. Brown et al., 2001; Schroetter et al., 2006; Lin et al., 2009). In this tectonic context, the Imbert Fm records the evolution of a forearc basin into a suture forearc basin in the upper Paleocene to middle Eocene, as a consequence of arc-continent collision and SSZ ophiolite emplacement.

This interpretation agrees with the general absence of continentally derived clasts in the Imbert Fm, such as marbles and micaschists of the Samaná metamorphic complex, suggesting that it is being subducted and metamorphosed beneath the accretionary prism (Escuder-Viruete et al., 2011b). The second phase ended with the compressive deformative event in the middle to upper Eocene that forms folds and thrust in the rocks of the Imbert Fm. This event has been related to the oblique collision of the Caribbean island arc with the Bahama Platform (Draper et al., 1994; de Zoeten and Mann, 1999).

The third phase includes the deposition of the El Mamey Group in the upper Eocene to lower Miocene. The deepmarine turbidite succession of the La Toca, Altamira and San Marcos Fms implies a period of tectonic subsidence following uplift. These units represent the infilling of a tectonically more mature and relatively stable, onlapping forearc basin. This indicates that uplift of the ophiolite and underlying metamorphic units was followed shortly by subsidence. Subsidence in the basin may have been produced by the progressive movement toward the $\mathrm{NE}$ of the orogenic wedge onto the continental margin (Fig. 12).

The Imbert Fm unconformably overlies the PPC and RSJC. This stratigraphic position and upwards gradation to the overlying El Mamey Group, is not compatible with a genesis for the Imbert Fm as sediments deposited in a trench or inner trench-slope basin, and then incorporated to a subduction complex (Bourgois et al., 1982; Pindell, 1985; Hernáiz Huerta et al., 2012). In this sense, the relationships between the Imbert Fm and the underlying SSZ ophiolite and overlying flysch deposits are similar to those of the La Picota Fm of eastern Cuba, the basal Great Valley Supergroup of the coastal California, the Saint-Daniel mélange in southern Quebec, the Ordovician South Mayo Trough of western Ireland and the olistostromes, mélanges and terrigenous sediments in Albania, overlying the corresponding Caribbean, Franciscan, Taconian/Grampian and Tethyan (Mirdita) ophiolites (Cobiella-Reguera, 2009; Dewey and Mange, 1999; Hitz and Wakabayashi, 2012; Robertson, 2002; Robertson et al., 2012; Ryan and Dewey, 2011; Schroetter et al., 2006). Therefore, there have been similar upper crustal processes during arc-continent collision in the past to the present. In the Greater Antilles orogenic belt, the Imbert Fm represents the base of a syn-collisional basin developed in a forearc setting during the arc-continent collision. 


\section{The Supplement related to this article is available online at doi:10.5194/se-7-11-2016-supplement.}

Acknowledgements. The authors wish to thank Gren Draper (Florida International University, Miami) for their comments on the geology of Dominican Republic and Jacques Monthel (BRGM) and Pedro-Pablo Hernáiz (Inypsa) for their involvement in mapping and sampling the Puerto Plata area. Gren Draper, Paul Ryan and Joaquina Álvarez-Marrón provided careful and constructive reviews. The Dominican Servicio Geológico Nacional is also thanked for collaboration, particularly to Ing. Santiago Muñoz. The research has been funded by the CGL2009-08674/BTE and CGL2012-33669/BTE projects.

Edited by: J. Alvarez-Marron

\section{References}

Abbott, R. N. and Draper, G.: The Case for UHP Conditions in the Cuaba Terrane, Rio San Juan Metamorphic Complex, Dominican Republic, Geol. Ac., 11, 149-165, 2013.

Agard, P., Yamato, P., Jolivet, L., and Burov, E.: Exhumation of oceanic blueschists and eclogites in subduction zones: Timing and mechanisms, Earth Sci. Rev., 92, 53-79, 2009.

Alonso, J. L., Marcos, A., and Suárez, A.: Structure and organization of the Porma mélange: Progressive denudation of a submarine nappe toe by gravitational collapse, Am. J. Sci., 306, 32-65 2006.

Alonso, J. L., Marcos, A., Villa, E., Súarez, A., Merino-Tomé, O. A., and Fernández, L. P.: Mélanges and other types of blockin-matrix formations in the Cantabrian Zone (Variscan Orogen, northwest Spain): origin and significance, Int. Geol. Rev., 57, 563-580, 2015.

Bourgois, J., Vila, J. M., Llinás, R., and Tavares, I.: Datos geológicos nuevos acerca de la región de Puerto Plata, República Dominicana, Transactions of the 9th Caribbean Geological Conference, Republica Dominicana, Amigo del Hogar Publishers, Santo Domingo, 35-38, 1982.

Bowin, C. and Nagle, F.: Igneous and metamorphic rocks of northern Dominican Republic. An uplifted subduction zone complex. Transactions of the 9th Caribbean Geological Conference, República Dominicana. Amigo del Hogar Publishers, Santo Domingo, Cloos y Shreve, 1988, 39-50, 1982.

Brown, D., Alvarez-Marron, J.,Perez-Estaun, A., Puchkov, V., Ayarza, P., and Gorozhanina, Y.: Structure and Evolution of The Magnitogorsk Forearc basin: Identifying Upper crustal Processes during arc-continent collision in the southern Urals, Tectonics, 20, 3, 364-375, 2001.

Calais, E., Bethoux, N., and Mercier de Lépinay, B.: From transcurrent faulting to frontal subduction: A seismotectonic study of the northern Caribbean plate boundary from Cuba to Puerto Rico, Tectonics, 11, 114-123, 1992.

Cobiella-Reguera, J. L.: Emplacement of the northern ophiolites of Cuba and the Campanian-Eocene geological history of the northwestern Caribbean-SE Gulf of Mexico region, edited by: James,
K. H., Lorente, M. A., and Pindell, J. L., The Origin and Evolution of the Caribbean Plate, Geological Society, London, Special Publications, 328, 315-338 2009.

Cowan, D. S.: Structural styles in Mesozoic and Cenozoic mélanges in the western Cordillera of North America, Geol. Soc. Am. Bull., 96, 451-462 1985.

Dewey, J. F. and Mange, M. A.: Petrography of Ordovician and Silurian sediments in the western Irish Caledonides: tracers of a short-lived Ordovician continent-arc collision orogeny and the evolution of the Laurentian Appalachian-Caledonian margin, Geological Society of London Special Publication, 164, 55-107 1999.

de Zoeten, R. and Mann, P.: Structural geology and Cenozoic tectonic history of the central Cordillera Septentrional, Dominican Republic, Geol. Soc. Am. Spec. Paper, 262, 265-279, 1991.

de Zoeten, R. and Mann, P.: Cenozoic El Mamey Group of Northern Hispaniola: a sedimentary record of subduction, collisional and strike-slip events within the North America-Caribbean Plate boundary zone, in: Caribbean Basins, edited by: Mann, P., Sedimentary Basins of the World, edited Series, vol. 4. Elsevier Science B.V., Amsterdam, 247-286, 1999.

Dickinson, W. R.: Forearc basins, in: Tectonic of sedimentary basins, edited by: Busby, C. J. and Ingersoll, R. V., Oxford, Blackwell Science, 221-261, 1995.

Draper, G. and Nagle, F.: Geology, structure, and tectonic development of the Río San Juan Complex, northern Dominican Republic, Geol. Soc. Am. Spec. Paper, 262, 77-95, 1991.

Draper, G., Mann, P., and Lewis, J. F.: Hispaniola, in: Caribbean Geology: An introduction, edited by: Donovan, S. K. and Jackson, T. A., Jamaica, University of the West Indies Publishers Association, 129-150, 1994.

Draut, A. E. and Clift, P. D.: Basins in Arc-Continent Collisions, John Wiley \& Sons, Ltd., 347-368, 2011.

Escuder-Viruete, J.: Petrología de rocas ígneas y metamórficas de la Cordillera Septentrional. Proyecto Sysmin. Dirección General de Minería, Santo Domingo, 54 pp., 2010.

Escuder-Viruete, J., Díaz de Neira, A., Hernáiz-Huerta, P. P., Monthel, J., García Senz, J., Joubert, M., Lopera, E., Ullrich, T., Friedman, R., Mortensen, J., and Pérez-Estaún, A.: Magmatic relationships and ages of Caribbean island arc tholeiites, boninites and related felsic rocks, Dominican Republic, Lithos, 90, 161186, 2006.

Escuder-Viruete, J., Joubert, M., Urien, P., Friedman, R., Weis, D., Ullrich, T., and Pérez-Estaún, A.: Caribbean island-arc rifting and backarc basin development in the Late Cretaceous: geochemical, isotopic and geochronological evidence from Central Hispaniola, Lithos, 104, 378-404, 2008.

Escuder-Viruete, J., Pérez-Estaún, A., Gabites, J., and SuárezRodríguez, Á.: Structural development of a high-pressure collisional accretionary wedge: The Samaná complex, northern Hispaniola, J. Struct. Geol., 33, 928-950, 2011 a.

Escuder-Viruete, J., Pérez-Estaún, A., Booth-Rea, G., and ValverdeVaquero, P.: Tectonometamorphic evolution of the Samaná complex, northern Hispaniola: Implications for the burial and exhumation of high-pressure rocks in a collisional accretionary wedge, Lithos, 125, 190-210, 2011b.

Escuder-Viruete, J., Friedman, R., Castillo-Carrión, M., Gabites, J., and Pérez-Estaún, A.: Origin and significance of the ophiolitic high-P mélanges in the northern Caribbean convergent mar- 
gin: insights from the geochemistry and large-scale structure of the Río San Juan metamorphic complex, Lithos, 127, 483-504, 2011c.

Escuder-Viruete, J., Valverde-Vaquero, P., Rojas-Agramonte, Y., Gabites, J., and Pérez-Estaún, A.: From intra-oceanic subduction to arc accretion and arc-continent collision: Insights from the structural evolution of the Río San Juan metamorphic complex, northern Hispaniola, J. Struct. Geol., 46, 34-56, 2013 a.

Escuder-Viruete, J., Valverde-Vaquero, P., Rojas-Agramonte, Y., Jabites, J., Carrión-Castillo, M., and Pérez-Estaún, A.: Timing of deformational events in the Río San Juan complex: implications for the tectonic controls on the exhumation of high-P rocks in the northern Caribbean subduction-accretionary prism, Lithos, 177, 416-435, 2013b.

Escuder-Viruete, J., Castillo-Carrión, M., and Pérez-Estaún, A.: Magmatic relationships between depleted mantle harzburgites, boninitic cumulate gabbros and subduction-related tholeiitic basalts in the Puerto Plata ophiolitic complex, Dominican Republic: Implications for the birthof the Caribbean island-arc, Lithos, 196/197, 261-280, 2014.

Festa, A., Pini, G. A., Dilek, and Codegone, G.: Mélanges and mélange-forming processes: a historical overview and new concepts, Int. Geol. Rev., 52, 1040-1105, 2010.

García-Casco, A., Iturralde-Vinent, M. A., and Pindell, J. L.: Latest Cretaceous collision/accretion between the Caribbean Plate and Caribeana: origin of metamorphic terranes in the Greater Antilles, Int. Geol. Rev., 50, 781-862, 2008.

Gradstein, F. M., Ogg, J. G., Schmitz, M. D., and Ogg, G. M.: The Geologic Time Scale 2012, vol. 1, Boston, Elsevier, p. 1144, 2012.

Gribble R. F., Stern R. J., Newman S., Bloomer S. H., and O'Hearn T.: Chemical and isotopic composition of lavas from the northern Mariana Trough: implications for magmagenesis in back-arc basins, J. Petrol., 39, 125-154, 1998.

Harris, R., Vorkink, M. W., Prasetyadi, C., Zobell, E., Roosmawati, N., and Apthorpe, M.: Transition from subduction to arccontinent collision: Geologic and neotectonic evolution of Savu Island, Indonesia, Geosphere, v. 5, 152-171, 2009.

Hernáiz-Huerta, P. P.: Mapa Geológico de la Hoja a E. 1: 50.000 no. 6075-III (Imbert), Proyecto SYSMIN de Cartografía Geotemática de la República Dominicana. Programa. Dirección General de Minería, Santo Domingo, 252 pp., 2010.

Hernáiz-Huerta, P. P, Pérez-Valera , F., Abad, M., Monthel, J., and Diaz de Neira, A.: Mélanges and olistostromes in the Puerto Plata area (northern Dominican Republic) as a record of subduction and collisional processes between the Caribbean and NorthAmerican plates., Tectonophysics, 568/569, 266-281, 2012.

Hitz, B. and Wakabayashi, J.: Unmetamorphosed sedimentary mélange with high-pressure metamorphic blocks in a nascent forearc basin setting, Tectonophysics, 568/569, 124-132, 2012.

Krebs, M., Maresch, W. V., Schertl, H. P., Baumann, A., Draper, G., Idleman, B., Münker, C., and Trapp, E.: The dynamics of intraoceanic subduction zones: a direct comparison between fossil petrological evidence (Rio San Juan Complex, Dominican Republic) and numerical simulation, Lithos, 103, 106-137, 2008.

Krebs, M., Shertl, H. P., Maresch, W. V., and Draper, G.: Mass flow in serpentinite-hosted subduction channels: P-T-t path patterns of metamorphic blocks in the Rio San Juan mélange (Dominican Republic), J. Asian Earth Sci., 42, 569-595, 2011.

Laó-Dávila, D. A., Llerandi-Román, P. A., and Anderson, T. H.: Cretaceous-Paleogene thrust emplacement of serpentinite in southwestern Puerto Rico, Geol. Soc. Am. Bull., 124, 11691190, 2012.

Lewis, J., Draper, G., Proenza, J., Espaillat, J., and Jimenez, J.: Ophiolite-related ultramafic rocks (serpentinites) in the Caribbean Region: a review of their occurrence, composition, origin, emplacement and NI-laterite soil formation, Geol. Acta, 4, 237-263, 2006.

Lin, A. T., Yao, B., Hsu, S.-K., Liu, C.-S., and Huang, C.-Y.: Tectonic Features of the Incipient Arc-Continent Collision Zone of Taiwan: Implications for Seismicity, Tectonophysics, 479, 2842, 2009.

Lucente, C. C. and Pini, G. A.: Anatomy and emplacement mechanism of a large submarine slide within the Miocene foredeep in the Northern Apennines, Italy: a field perspective, Am. J. Sci., 303, 565-602, 2003.

Mann, P., Draper, G., and Lewis, J. F.: An overview of the geologic and tectonic development of Española, Geol. Soc. Am. Spec. Paper, 262, 1-28, 1991.

Mann, P., Calais, E., Ruegg, J. C., Demets C., Jansma, P. E., and Mattioli, G. S.: Oblique collision in the northeastern Caribbean from GPS measurements and geological observations, Tectonics, 21, 1-26, 2002.

Marchesi, C., Garrido, C. J., Godard, M., Proenza, J. A., Gervilla, F., and Blanco-Moreno, J.: Petrogenesis of highly depleted peridotites and gabbroic rocks from the Mayarí-Baracoa Ophiolitic Belt (eastern Cuba), Contrib. Mineral. Petrol., 151, 717-736, 2006.

Marchesi, C., Garrido, C. J., Godard, M., Belley, F., and Ferré, E.: Migration and accumulation of ultra-depleted subduction-related melts in the Massif du Sud ophiolite (New Caledonia), Chem. Geol., 266, 180-195, 2009.

Marrett, R. A. and Allmendinger, R. W.: Kinematic analysis of fault-slip data, J. Struct. Geol., 12, 973-986, 1990.

Monthel, J.: Mapa Geológico de la Hoja a E. 1 : 50.000 no. 6075I (Puerto Plata), Proyecto SYSMIN de Cartografía Geotemática de la República Dominicana, Programa, Dirección General de Minería, Santo Domingo, p. 310, 2010.

Nagle, F.: Geology of the Puerto Plata area, Dominican Republic (Hispaniola): tectonic focal point of the Northern Caribbean, in: Three Geologic Studies in the Dominican Republic, edited by: Lidz, B., and Nagle, F., Miami Geological Society, Miami, 1-28, 1979.

Pearce, J. A. and Peate, D. W.: Tectonic implications of the composition of volcanic arc magmas, Earth Planet. Sci. Ann. Rev., 23, 251-285, 1995.

PetDB: Petrological database of the ocean floor, http://www. earthchem.org/petdb, 2007.

Pindell, J.: Plate tectonic evolution of the Gulf of Mexico and the Caribbean region, PhD Thesis (unpublished), Durhan University, England, 287 pp., 1985.

Pindell, J. L. and Draper, G.: Stratigraphy and geological history of the Puerto Plata area, northern Dominican Republic, Geol. Soc. Am. Spec. Paper, 262, 97-114, 1991.

Pindell, J. L. and Kennan, L.: Tectonic evolution of the Gulf of Mexico, Caribbean and northern South America in the mantle 
reference frame: an update, in: The Origin and Evolution of the Caribbean Plate, edited by: James, K. H., Lorente, M. A., and Pindell, J. L. Geological Society, London, Special Publications, 328, 1-55, 2009.

Pini, G. A., Ogata, K., Camerlenghi, A., Festa, A., Lucente, C. C., and Codegone, G.: Sedimentary mélanges and fossil masstransport complexes: a key for better understanding submarinemassmovements?, in: Submarine mass movements and their consequences, edited by: Yamada, et al., Adv. Nat. Technol. Haz. Res., 31. Springer Science+Business Media B.V., 585-593, 2012.

Robertson, A. H. F.: Overview of the genesis and emplacement of mesozoic ophiolites in the Eastern Mediterranean Tethyan Region, Lithos, 65, 1-67, 2002.

Robertson, A. H. F., Ionescu, C., Hoeck, V., Koller, F., Onuzi, K., Bucur, I. I., and Ghega, D.: Emplacement of the Jurassic Mirdita ophiolites (southern Albania): evidence from associated clastic and carbonate sediments, Int. J. Earth Sci., 10, 1437-3254, 2012.

Ryan, P. D. and Dewey, J. F.: Arc-continent collision in the Ordovician of western Ireland: stratigraphic, structural and metamorphic evolution, in Arc-continent collision, edited by: Brown, D. and Ryan, P.D., Frontiers in Earth Sciences, Springer Verlag, Berlin Heidelberg, 373-401, 2011.

Saumur, B. M., Hattori, K. H., and Guillot, S.: Contrasting origins of serpentinites in a subduction complex, northern Dominican Republic, Geol. Soc. Am. Bull., 122, 292-304, 2010.
Schroetter, J. M., Tremblay, A., Bédard, J. H., and Villeneuve, M. E.: Syncollisional basin development in the Appalachian Orogen: the St-Daniel Mélange, southern Québec, Canada, Bull. Geol. Soc. Am., 118, 109-125, 2006.

Stanek, K. P., Maresch, W. V., and Pindell, J. L.: The geotectonic story of the northwestern branch of the Caribbean arc: implications from structural and geochronological data of Cuba, edited by: James, K. H., Lorente, M. A., and Pindell, J. L., The Origin and Evolution of the Caribbean Plate, Geological Society, London, Special Publications, 328, 1-55, 2009.

Suárez-Rodríguez, A., Escuder-Viruete, J., and ColmeneroHidalgo, E.: Nuevos datos sobre la geología y la edad de la Mélange de San Marcos, Cordillera Septentrional, República Dominicana. Resúmenes y Programa de Ponencias. 2do. Congreso Dominicano de Geología, Santo Domingo, 12 pp., 2013.

Suárez-Rodríguez, A., Escuder-Viruete, J., and ColmeneroHidalgo, E.: Nuevos datos sobre la naturaleza, origen y edad de la Mélange de San Marcos, Cordillera Septentrional de la República Dominicana, Boletín Geológico y Minero, IGME, Madrid, in press, 2015.

Sun, S. S. and McDonough, W. F.: Chemical and isotopic systematics of oceanic basalts: Implications for mantle compositions and processes, in: Magmatism in the Ocean Basins, edited by: Saunders, A. D. and Norry, M. J., Geol. Soc. Spec. Publication, 42, 313-345, 1989.

von Huene, R. and Scholl, D. W.: Observations at convergent margins concerning sediment subduction, erosion, and the growth of continental crust: Rev. Geophys., 29, 279-316, 1991.

Yen, J.-Y. and Lundberg, N.: Sediment Compositions in Offshore Southern Taiwan and Their Relations to the Source Rocks in Modern Arc-Continent Collision Zone, Mar. Geol., 225, 247-63, 2006. 